\title{
Chiral Stationary Phases for Liquid Chromatography Based on Chitin- and Chitosan-Derived Marine Polysaccharides
}

\author{
João Ribeiro $^{1}$ (D), Maria Elizabeth Tiritan ${ }^{1,2,3}$, Madalena M. M. Pinto ${ }^{1,2}$ (D) and \\ Carla Fernandes $1,2, *$ \\ 1 Laboratório de Química Orgânica e Farmacêutica, Departamento de Ciências Químicas, Faculdade de \\ Farmácia, Rua de Jorge Viterbo Ferreira 228, 4050-313 Porto, Portugal; joaobigi@gmail.com (J.R.); \\ elizabeth.tiritan@iucs.cespu.pt (M.E.T.); madalena@ff.up.pt (M.M.M.P.) \\ 2 Interdisciplinary Centre of Marine and Environmental Research (CIIMAR), Edifício do Terminal de \\ Cruzeiros do Porto de Leixões, Av. General Norton de Matos s/n, 4050-208 Matosinhos, Portugal \\ 3 CESPU, Instituto de Investigação e Formação Avançada em Ciências e Tecnologias da Saúde (IINFACTS), \\ Rua Central de Gandra, 1317, 4585-116 Gandra PRD, Portugal \\ * Correspondence: cfernandes@ff.up.pt; Tel.: +351-220428688
}

Received: 1 August 2017; Accepted: 6 September 2017; Published: 11 September 2017

\begin{abstract}
The development of chiral stationary phases (CSPs) for liquid chromatography (LC) revolutionized the enantioseparation and, nowadays, different types of CSPs are commercially available. Polysaccharide-based CSPs are one of the most versatile and widely used for both analytical and preparative applications and they are able to resolve several classes of racemates. Phenylcarbamates of amylose and cellulose derivatives are the most successful; however, polysaccharide-based CSPs comprising marine-derived polysaccharides are also described revealing high chiral recognition abilities and wider range of mobile phases. A literature survey covering the report on chitin and chitosan based CSPs is presented. The chemical structure of the chiral selectors, their development and applications in chiral LC are emphasized.
\end{abstract}

Keywords: liquid chromatography; chiral stationary phases; marine polysaccharides; chitin; chitosan

\section{Introduction}

Nowadays, there are several types of chiral stationary phases (CSPs), including Pirkle-type, ligand-exchange-type, crown ether-based, cyclodextrin-based, macrocyclic antibiotics-based, ion-exchange-type, polysaccharide-based, molecular imprinted, synthetic polymer-based, proteinbased, among others [1-4].

Polysaccharides are polymers comprising several units of monosaccharides linked to each other by a glycosidic bond [5]. There are several types of polysaccharides, and some of them have been studied as possible chiral selectors for LC (Figure 1).

The first study reporting the use of polysaccharide derivatives as a practical chiral packing material for LC columns was described by Hesse and Hagel in 1973 [6]. Therefore, several polysaccharides were derivatized, and coated on macroporous aminopropyl silica. Cellulose and amylose-based CSPs showed the best chiral recognition for all the tested analytes [7]. Phenylcarbamates, esters, alkylcarbamates and benzylcarbamates derivatives of cellulose and amylose derivatives were developed as selectors for CSPs. Since then, other research groups have demonstrated interest in the development of amylose [8-15] and cellulose [10,14,16-21] derivatives as CSPs, including coating onto microporous silica $[9,22,23]$. Several reviews focusing the preparation and evaluation of this type of CSPs can be found [24-34]. Phenylcarbamates are the derivatives most studied due to 
their high chiral ability recognition and the possibility to explore different aryl substituents [35-41]. The tris-phenylcarbamate CSPs generally have high enantioseparation abilities however, the chiral recognition is greatly influenced by the substituents present on the phenyl moiety of the phenylcarbamates [7-9,13,42]. Among the developed amylose and cellulose tris-phenylcarbamates, the 3,5-dimethylphenyl derivatives proved to have the best enantiorecognition performance $[8,9,43,44]$ being, nowadays, the most widely used CSPs (Figure 2).

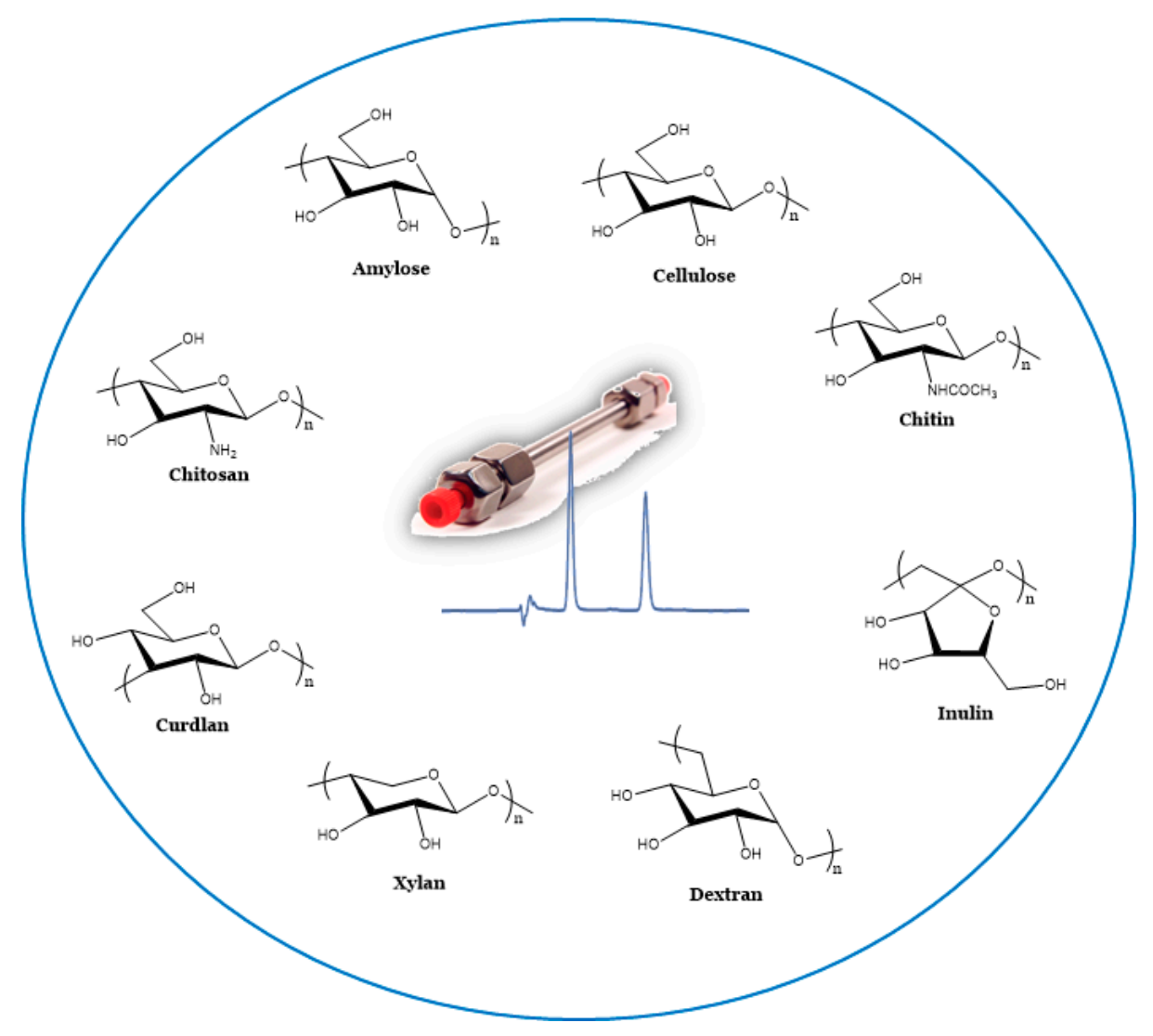

Figure 1. Structures of different types of polysaccharides studied as selectors for liquid chromatography (LC).

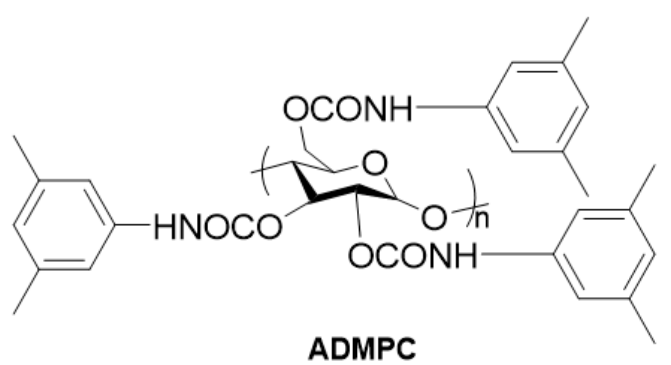

ADMPC

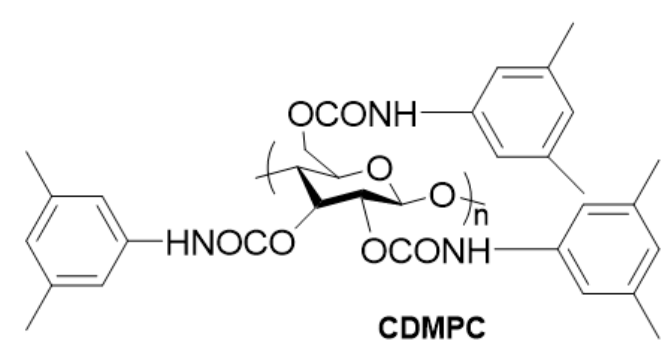

CDMPC

Figure 2. Structures of amylose 3,5-dimethylphenylcarbamate (ADMPC) and cellulose 3,5-dimethylphenylcarbamate (CDMPC).

The carbamate derivatives of amylose and cellulose can be synthesized by reaction of the polysaccharide with the corresponding isocyanate comprising the moiety of the desired derivative for the CSP $[7,8,43]$. The phenylcarbamates of amylose and cellulose can be coated $[7,8,11]$ or be immobilized [25-27,45] on a chromatographic support, mainly aminopropyl silica. 
Although the coated CSPs show high chiral recognition abilities for a wide variety of racemates, the range of mobile phases that can be used is very limited. Mobile phases containing organic solvents such as tetrahydrofuran, dichloromethane or ethyl acetate, among others, are not suitable for the coated CSPs. The immobilization of phenylcarbamates of amylose and cellulose was carried out to solve this problem [31,32]. However, the immobilized CSPs have also some drawbacks. Their lower chiral recognition ability is the main disadvantage, which can be explained by the fact that the immobilization of the polysaccharide derivative on the chromatographic support is done through the hydroxyl groups, causing a disturbance in the high-ordered structures of the polysaccharide [27].

\section{Marine Polysaccharide-Derived CSPs}

Marine-derived polysaccharides have also been exploited as chiral selectors, and some of them proved to be good alternatives to amylose and cellulose derivatives.

Braconnot discovered chitin, a marine polysaccharide obtained by isolation from shells of crustaceans and mollusks, in the early 19th century [46]. Chitin is one of the most abundant polysaccharides comprising $N$-acetyl-D-glucosamine units linked by $\beta-(1,4)$.

Chitosan is a 2-deoxy-2-glucosamine polysaccharide, discovered in 1859 by Rouget after deacetylation of chitin by boiling in concentrated potassium hydroxide solution [47]. Both marine-derived polysaccharides have diverse applications whether in medicine as wound healing agents [48], as drug carriers [49,50], in bone tissue regeneration [51] as well as in the food industry as clarification agents [52], among others. Another important application is their use as suitable chiral selectors for LC [26]. In fact, they have been used as CSPs, since Okamoto et al., in 1984, introduced the first phenylcarbamate of chitosan. Considering chitin, the first reported study was published by Cass et al., in 1996, describing the chiral discrimination ability of two arylcarbamates of chitin [53].

A literature survey covering the report on chitin and chitosan based CSPs is the main objective of this review. Different CSPs were developed allowing the enantioresolution of several different analytes $(\alpha>1.00)$ (Tables 1-6).

The structures of the separated analytes (A1-A73) are shown in Figures 3 and 4.

\subsection{Chitin-Based CSPs}

The bis-phenylcarbamate (1) and bis-3,5-dimethylphenylcarbamate (2) (Table 1), coated on microporous aminopropyl silica, were the first described chitin-based CSPs [53]. Two distinct sources of chitin (commercial and noncommercial) were used for the preparation of both polysaccharide derivatives. Interestingly, the results obtained demonstrated that the chiral discrimination of both aryl carbamate derivatives was significantly affected by the source of chitin used. For example, from the series of racemates tested, only $(E)$-1-chloro-1,2-diphenylethane oxide was resolved on the CSPs prepared using a commercial chitin, with $\alpha$ values of 1.5 and 2.0 in CSPs 1 and 2, respectively. The similar bis-aryl carbamate derivatives of a noncommercial chitin presented higher resolution power compared with commercial chitin. These results are due to the differences related to the resource and method used for isolation and purification of chitin, which can influence its quality and, consequently, the length of its molecular chain, number of acetyl groups as well as the 3D structure [53]. Yamamoto et al., developed a chiral selector from chitin, the bis-3,5-dichlorophenylcarbamate (3) (Table 1) as well as both derivatives previously described (1 and 2) to study the influence of the aryl groups as substituents on chiral discrimination performance [54]. Among the three, the bis-3,5-dimethylphenylcarbamate (2) and bis-3,5-dichlorophenylcarbamate (3) exhibited, in general, higher chiral recognition than bis-phenylcarbamate (1). Moreover, some chiral 2-arylpropionic acids such as ketoprofen and ibuprofen were efficiently resolved on bis-3,5-dichlorophenylcarbamate (3) with $\alpha$ values of 1.72 and 1.39, respectively [54]. In a continuous interest in developing new chitin-based CSPs, the same group developed 3,5-disubstituted (2-5) and several 4-substituted phenylcarbamate (6-13) chitin derivatives in an extensive study that also included three cycloalkylcarbamates (14-16) and both configurations of one optically active arylalkylcarbamate (17) (Table 1) [54]. All CSPs were 
obtained by coating the chitin derivatives on macroporous silica gel. The nature of the substituents as well as their position on the phenyl moiety of the carbamate demonstrated to have a significant role on chiral recognition. It was proposed that the polar carbamates and acetamide residues of the chitin phenylcarbamates were the most important interaction sites for chiral recognition, with the substituents of the phenyl group having influence on the polarities of these sites [55]. Regarding the chitin 3,5-disubstituted phenylcarbamates, the 3,5-dimethylphenylcarbamate (2) showed the highest chiral recognition although the remaining three 3,5-disubstituted phenylcarbamates (3-5) also presented good chromatographic results. Additionally, the 3,5-dimethyl- (2) and 3,5-dichlorophenylcarbamates (3) demonstrated some complementary in terms of enantiorecognition. Considering the 4-substituted phenylcarbamates of chitin (6-13), some interesting results were obtained. The 4-methylphenyl- (8), 4-chlorophenyl- (11) and 4-trifluoromethylphenyl- (12) carbamates showed the highest enantiorecognition while 4-tert-butyl- (6) and 4-isopropylphenyl- (7) carbamates presented lower retention and enantioselectivity for the tested racemates. The CSPs comprising the cycloalkylcarbamates $\mathbf{1 5}$ and $\mathbf{1 6}$ revealed relatively low enantiorecognition, both resolving only two of the ten analyzed racemates, the 2,2'-dihydroxy-6,6'-dimethylbiphenyl ( $\alpha=1.09$ and $\alpha=1.03$, respectively) and 2-phenylcyclohexanone ( $\alpha=1.29$ and $\alpha=1.24$, respectively) [54]. For both enantiomers of chitin 1-phenylethylcarbamate (17), low chiral recognition ability was observed which was depended on their configuration. For example, (S)-1-phenylethylcarbamate of chitin showed enantioselectivity for benzoin, 2-phenylcyclohexanone and 1-(9-anthryl)-2,2,2-trifluoroethanol, whereas no separation was observed for these analytes with its antipode CSP, which separated other racemates (Table 1).

Considering that the chitin derivatives have a very low solubility, the possibility to perform enantioseparations under reversed phase as well as using different solvents in normal phase, such as chloroform and ethyl acetate, was also studied (Table 1). Both chromatographic elution conditions were tested for 3,5-dimethyl- (2) and 3,5-dichlorophenylcarbamates (3) and, in some cases, the racemates were more efficiently resolved under reversed phase mode [55].

Following the same strategy, and aiming the enantioseparation of tadalafil and its intermediates, Zhang et al., synthesized new chitin bis-arylcarbamates, specifically chitin 3-chloro-4-methyl- (18), 4-trifluoromethoxy- (19) and 4-chloro-3-trifluoromethyl- (20) phenylcarbamates (Table 1) [56]. The three chitin derivatives were coated on macroporous 3-aminopropyl silica and the obtained CSPs were successful in the enatioresolution of all tested analytes [56].

Recently, the same group developed a new strategy to enhance the chromatographic performance of chitin-based CSPs $[57,58]$. The aim was combining amylose or cellulose with chitin derivatives and coated on silica gel to improve the chiral recognition as well as their stability and solvent resistance. The first report of this type of biselector as CSPs comprised amylose tris-3,5-dimethylphenylcarbamate and chitin bis-3-chloro-4-methylphenlcarbamate (18) blended at different molar ratios [58]. Although the chiral recognition of the blended CSPs did not improve significantly, comparing to the single selector CSPs, there was a great improvement in the solvent tolerance and stability. Interestingly, the biselector CSPs prepared by blending chitin bis-3,5-dimethylphenylcarbamate (3) with cellulose bis-4-methylbenzoate and cellulose bis-3,5-dimethylphenylcarbamate sowed better chiral recognition capabilities compared to the corresponding single selectors [57]. They can also work in a wider range of mobile phases.

All the described chitin-based CSPs were prepared by coating method and, to the best of our knowledge, there is no studies reporting immobilized chitin derivatives as well as commercially available chitin-based CSPs. 


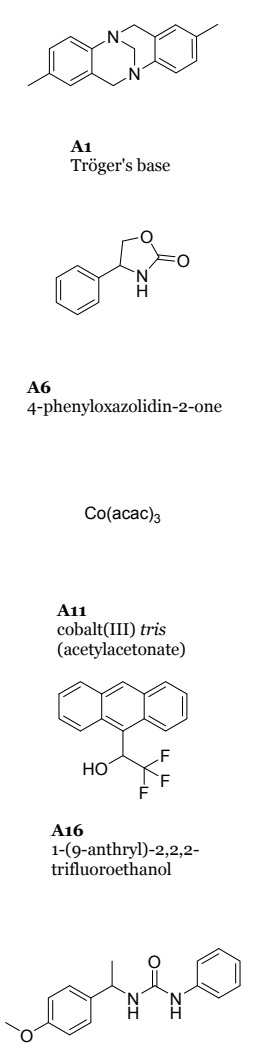
A21
1-(1-(4-methoxyphenyl)ethyl)-3-
phenylurea<smiles>COc1ccc(C(C)NC(=O)c2cc([N+](=O)[O-])cc([N+](=O)[O-])c2)cc1</smiles>

A26
$N$-(1-(4-methoxyphenyl)ethyl)-3,5-
dinitrobenzamide<smiles>CN1CC2CCC1CC(OC(=O)C(CO)c1ccccc1)C2</smiles>

A31
atropine<smiles>CN(C)CCCC(O)(c1ccc(F)cc1)c1ccc(C#N)cc1CO</smiles>

A36 4-(4-(dimethylamino)-1-(4fluorophenyl)-1-hydroxybutyl)-
(hydroxymethyl)benzonitrile

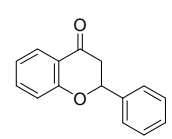

A2
flavanone

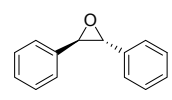

A7

trans-stilbene oxide
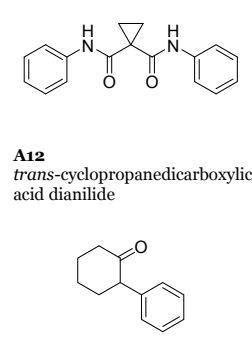

A17

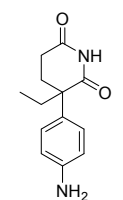

A22
aminoglutethimide

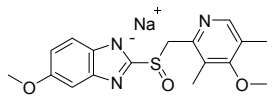

A27

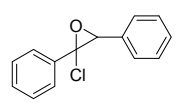

A32

32 1 -chloro-1,2-diphenylethene oxide

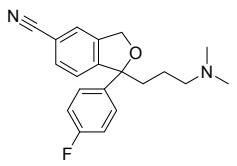

A37
citalopram

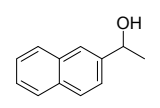

A3
1-(2-naphthyl)-ethanol

A4
methyl phenyl sulfoxide

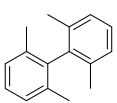

A8
$2,2,2^{\prime}, 6,6^{\prime}$-tetramethyl-1,1'-
biphenyl

A9
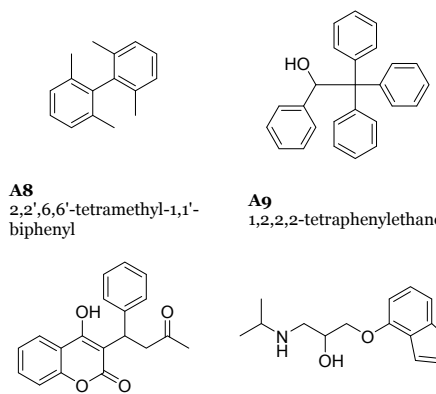

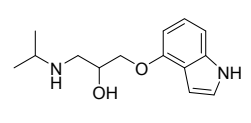

A13
warfarin

A14
pindolol<smiles>Cc1ccc(NC(=O)NC(C)c2ccccc2)cc1</smiles>

A18
1-(1-phenylethyl)-3-(p-

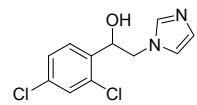

A19

1-(2,4-dichlorophenyl)-2-

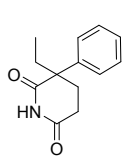

(NBr)

A23
glutethimide

citalo

citalopram hydrobromide<smiles>CC(c1cncnc1)C(Cn1cncn1)c1ccc(F)cc1F</smiles><smiles>CC(NC(=O)c1ccccc1)c1ccccc1</smiles>

A28

voriconazole<smiles>CC(C)CC(NC(=O)c1cc([N+](=O)[O-])cc([N+](=O)[O-])c1)C(=O)O</smiles><smiles>CC(NC(=O)c1ccccc1)c1ccccc1</smiles>

A34

A33
N-(3,5-dinitrobenzoyl)
leucine
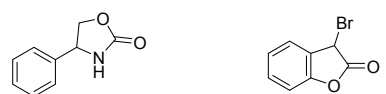

4-phe

A39

A15
$2,2^{\prime}$-dihydroxy-6,6'-dimethylbipheny

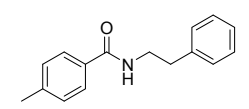

A2o
4-methyl- $N$-(phenylethyl)benzamide<smiles>O=C1Nc2ccc(Cl)cc2C(C#CC2CC2)(C(F)(F)F)O1</smiles>

A25
efavirenz

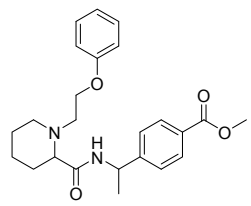

A30

methyl 4-(1-(1-(2-phenoxyethyl) carboxamido)ethyl)benzoate

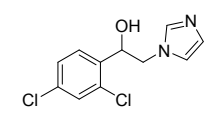
A35
1-(2,4-dichlorophenyl)-2-(1H-imidazol-1-
yll)ethanol

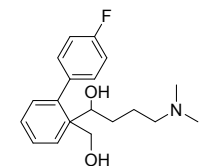

A40
4-(dimethylamino)-1-(4-fluorophenyl-14-(dinethylanio)-1-(4-Huoropheny

Figure 3. Chemical structures of the analytes A1-A40 separated in chitin and chitosan based CSPs. 


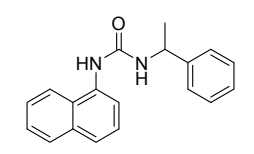

A41
1-(naphthalene-1-yl)-3-(11-(naphthalene-1-y
phenylethyl)urea<smiles>COc1cc(OC)cc(C(=O)NC(C)c2ccccc2)c1</smiles>

A46
3,5-dimethoxy- $N$-(1-phenylethyl)benzamide

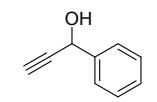

A51
1-phe

1-phenyl-2-propyn-1-ol<smiles>CCC(=O)NC(C)c1ccccc1</smiles>

$$
\begin{aligned}
& \text { A56 } \\
& N \text {-(1-phenylethyl)- } \\
& \text { propionamide }
\end{aligned}
$$<smiles>CN1C(=O)C(O)N=C(c2ccccc2)c2cc(Cl)ccc21</smiles>

A61
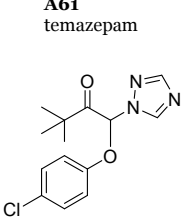

A66
triadimefon

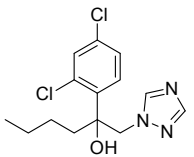

A71

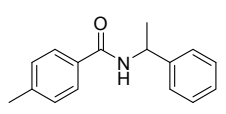

442 4-methyl- $N$ -

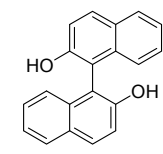

A47

1,1'-binaphthyl-2,2'-diol

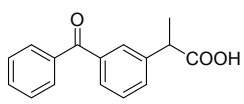

A52<smiles>COC(=O)C(C)NC(=O)c1cc(C)cc(C)c1</smiles>

A57
methyl (3.5-

dimethylbenzoyl)alaninate

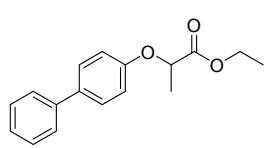

462

ethyl 2-([1,1'-biphenyl]-4-

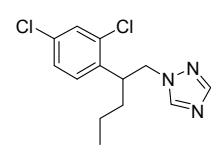

A67
penconazole

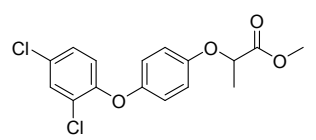

A72
diclofop-methyl

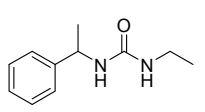

A43

thyl-3-(1-phenylethyl)urea

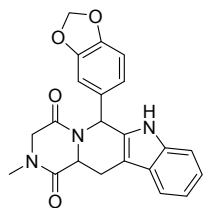

$\mathbf{A 4 8}$
tadalafil<smiles>OCC(O)c1ccccc1</smiles>

A53
1-phenylethane-1,2-diol

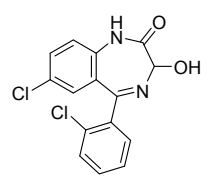

A58
lorazepam

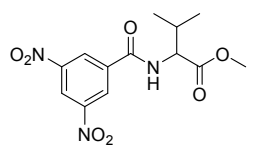

A63

methyl $\left(3,5^{-}\right.$
dinitrobenzoyl)valinate

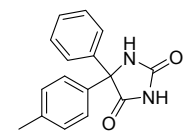

A68

5-phenyl-5-(4-
tolyl)hydantoin

$\left(\mathrm{C}_{9} \mathrm{H}_{8}\right)\left(\mathrm{\mu}_{3}-\mathrm{S}\right)$ WFeMo $(\mathrm{CO})_{7}\left(\mathrm{n}^{5}-\right.$

$\mathrm{C}_{5} \mathrm{H}_{4} \mathrm{COMe}$ )

A73
tetrahedrane metal cluster<smiles>CC(NC(=O)c1cc([N+](=O)[O-])cc([N+](=O)[O-])c1)c1ccccc1</smiles><smiles>Cc1cccc([N+](=O)[O-])c1-c1c(C)cccc1[N+](=O)[O-]</smiles>

A44

$\begin{array}{ll}\text { 3,5-dinitro- } N \text {-(1-phenylethyl)- } & \mathbf{A 4 5} \\ \text { benzamide } & \text {-dimethyl-6,6'-dinitro-1,1'- }\end{array}$ biphenyl

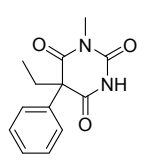

A49

mephobarbital

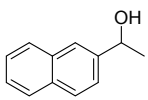

A54<smiles>CN1C(=O)C(O)N=C(c2ccccc2Cl)c2cc(Cl)ccc21</smiles>

A59
lormetazepam

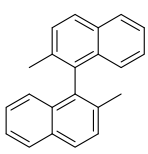

A64

2,2'-dimethyl-1,1-
binaphthalene

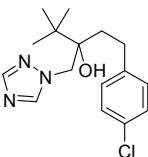

A69

tebuconazole<smiles>CC(NC(=O)c1cc([N+](=O)[O-])cc([N+](=O)[O-])c1)c1ccc2ccccc2c1</smiles>

A50
$N$-(1-(naphthalen-2-yl)ethyl)-3,5dinitrobenzamide

$$
\text { II) }
$$

A55

3-(dimethylamino)-1-(thiophen-2-<smiles>O=C1Nc2ccc(Cl)cc2C(c2ccccc2)=NC1O</smiles>

A6o
oxazepa<smiles>COC(=O)C(Cc1ccccc1)NC(=O)c1cc([N+](=O)[O-])cc([N+](=O)[O-])c1</smiles>

A65

dinitrobenzoyl)phenylalaninate<smiles>CC(OC(=O)c1cc([N+](=O)[O-])cc([N+](=O)[O-])c1)c1ccc2ccccc2c1</smiles>

A70

1-(naphthalen-2-yl)ethyl 3,5dinitrobenzoate

Figure 4. Chemical structures of the analytes A41-A73 separated in chitin and chitosan based CSPs. 
Table 1. Chitin-based chiral stationary phases (CSPs).

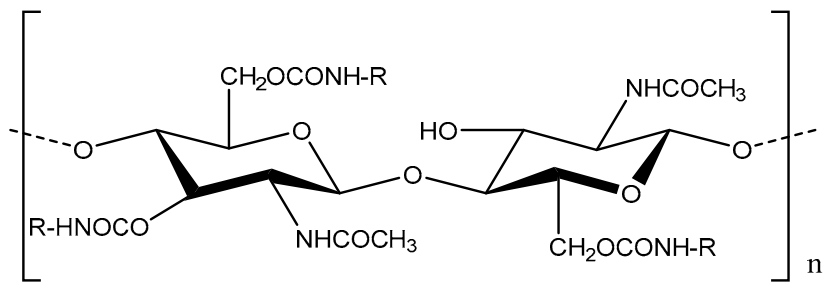

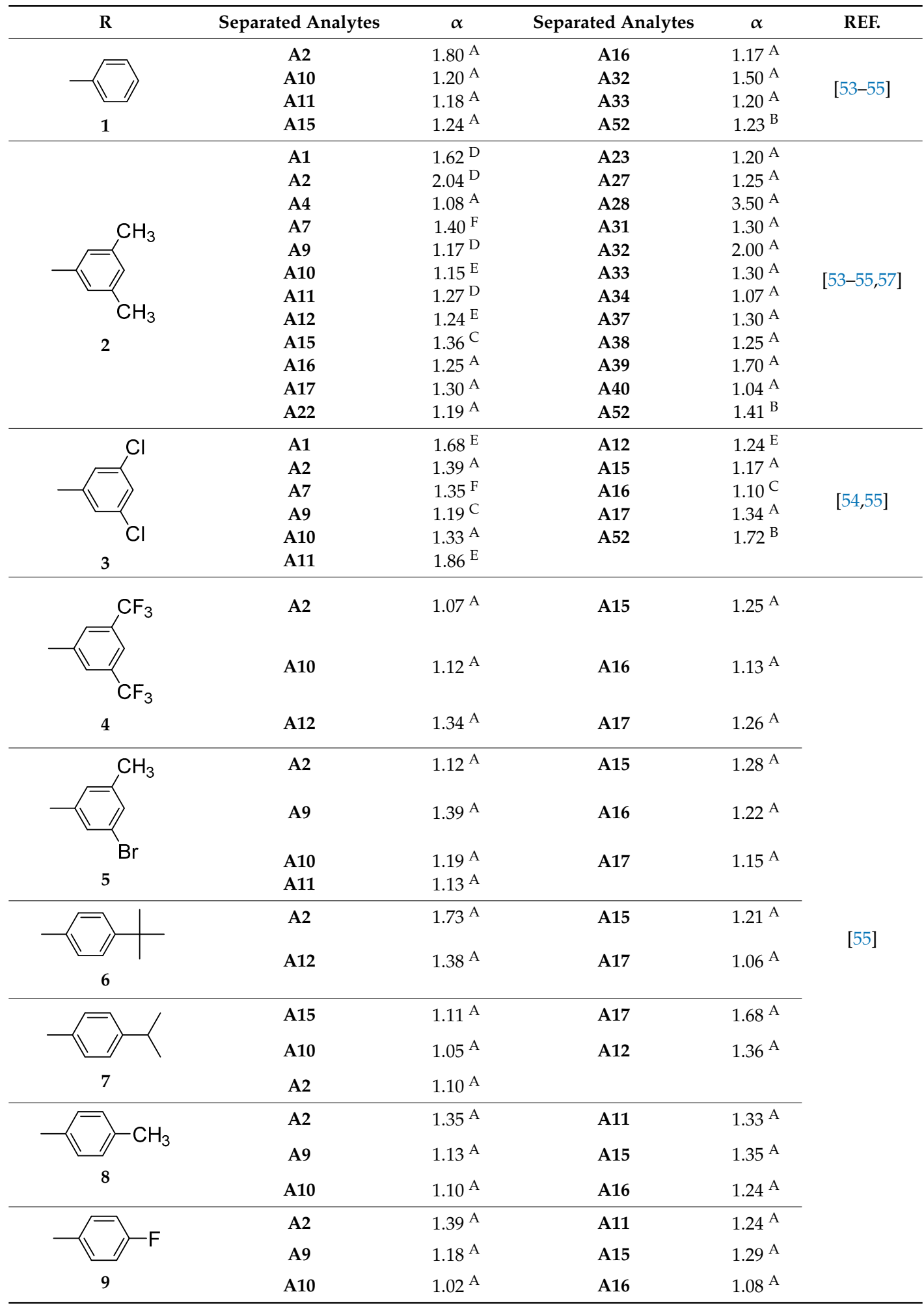


Table 1. Cont.

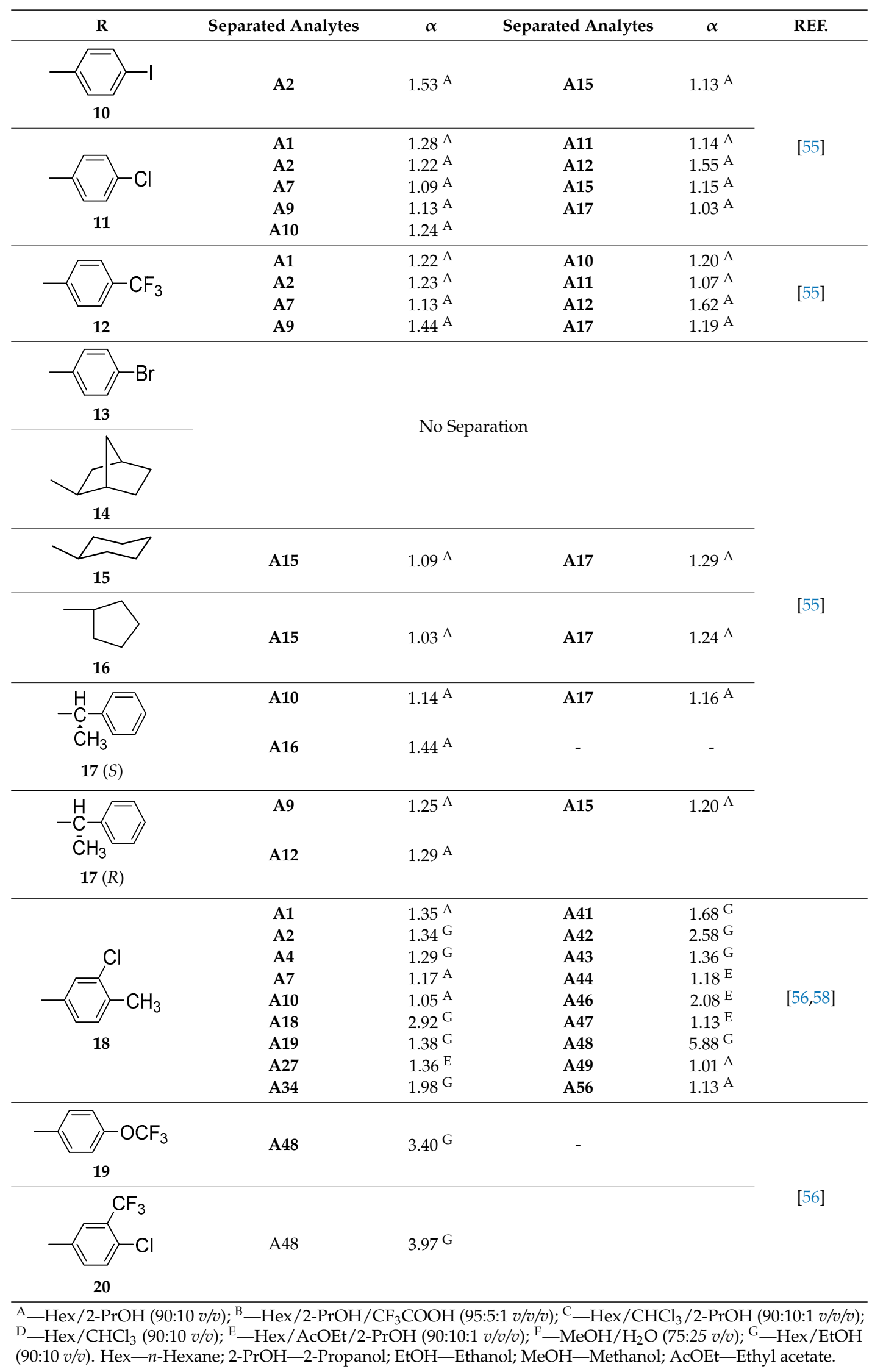




\subsection{Chitosan-Based CSPS}

Several studies regarding chitosan-based CSPs are found in literature. The first studies were focused mainly on tris-phenylcarbamates of chitosan. In the last decades, an increasingly number of bis-phenylcarbamates of chitosan have been described. Furthermore, besides the traditional coating method, same chitosan-based CSPs were prepared by immobilization of the chitosan-derivatives on the chromatographic support.

\subsubsection{Chitosan Tris-Carbamate CSPs}

As previously mentioned, the first study of a chitosan derivative as a CSP was published by Okamoto et al., in 1984 [7]. In this study, they compared the chiral discrimination ability of various polysaccharide phenylcarbamates as CSPs. Chitosan tris-phenylcarbamate derivative (21) coated on macroporous aminopropyl silica was found to resolve the enantiomers of 1-(9-anthryl)2,2,2-trifluoroethanol with a $\alpha$ value of 2.25 (Table 2) [7].

Table 2. Chitosan tris-carbamate CSPs.

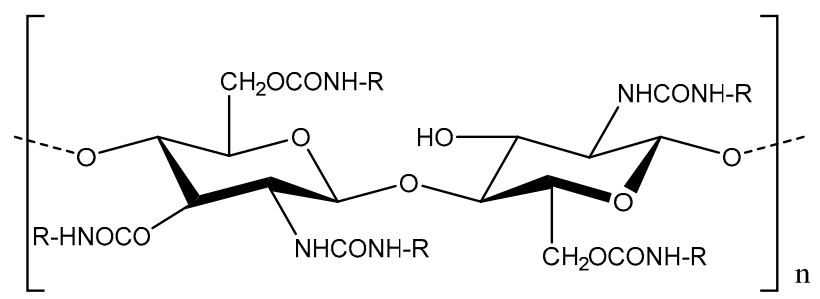

\begin{tabular}{|c|c|c|c|c|c|}
\hline $\mathbf{R}$ & Separated Analytes & $\alpha$ & Separated Analytes & $\alpha$ & REF. \\
\hline & A2 & $1.29^{\mathrm{A}}$ & A16 & $2.25^{\mathrm{A}}$ & \multirow{3}{*}[7,59]{} \\
\hline & A7 & $1.42^{\mathrm{A}}$ & A45 & $1.15^{\mathrm{A}}$ & \\
\hline 21 & A10 & $1.16^{\mathrm{A}}$ & A51 & $1.10^{\mathrm{A}}$ & \\
\hline & A1 & $1.08^{\mathrm{A}}$ & A12 & $1.14^{\mathrm{A}}$ & \multirow{6}{*}{ [59-62] } \\
\hline & A2 & $1.23^{\mathrm{A}}$ & A16 & $1.29^{\mathrm{A}}$ & \\
\hline & A7 & $1.05^{\mathrm{A}}$ & A17 & $1.20^{\mathrm{A}}$ & \\
\hline & A9 & $1.20^{\mathrm{A}}$ & A45 & $2.73^{\mathrm{A}}$ & \\
\hline $\mathrm{Cl}$ & A10 & $1.90^{\mathrm{A}}$ & A47 & $1.08^{\mathrm{A}}$ & \\
\hline 22 & A11 & $1.06^{\mathrm{A}}$ & A51 & $1.11^{\mathrm{A}}$ & \\
\hline & A7 & $1.20^{\mathrm{D}}$ & A57 & $1.12^{\mathrm{A}}$ & \multirow{7}{*}[61]{} \\
\hline & A10 & $1.10^{\mathrm{A}}$ & A58 & $1.22 \mathrm{~A}$ & \\
\hline & A13 & $1.22^{\mathrm{A}}$ & A59 & $1.09^{\mathrm{A}}$ & \\
\hline & A32 & $1.23^{\mathrm{D}}$ & A60 & $1.27^{\mathrm{A}}$ & \\
\hline & A44 & $1.06^{\mathrm{D}}$ & A61 & $1.07^{\mathrm{A}}$ & \\
\hline & A47 & $1.03^{\mathrm{D}}$ & A62 & $1.15^{\mathrm{D}}$ & \\
\hline 221 & A50 & $1.25^{\mathrm{A}}$ & A63 & $1.19^{\mathrm{D}}$ & \\
\hline $\mathrm{CH}_{3}$ & A1 & $1.51^{\mathrm{A}}$ & A12 & $1.80^{\mathrm{A}}$ & \multirow{6}{*}[59,60,62]{} \\
\hline & $\mathrm{A} 2$ & $1.60^{\mathrm{A}}$ & A15 & $1.14^{\mathrm{A}}$ & \\
\hline & A7 & $1.54^{\mathrm{A}}$ & A16 & $1.78^{\mathrm{A}}$ & \\
\hline & A9 & $1.51^{\mathrm{A}}$ & A17 & $1.24^{\mathrm{A}}$ & \\
\hline $\mathrm{CH}_{3}$ & A10 & $1.59^{\mathrm{A}}$ & A47 & $1.13^{\mathrm{A}}$ & \\
\hline 23 & A11 & $1.25^{\mathrm{A}}$ & A51 & $1.34^{\mathrm{A}}$ & \\
\hline
\end{tabular}


Table 2. Cont.

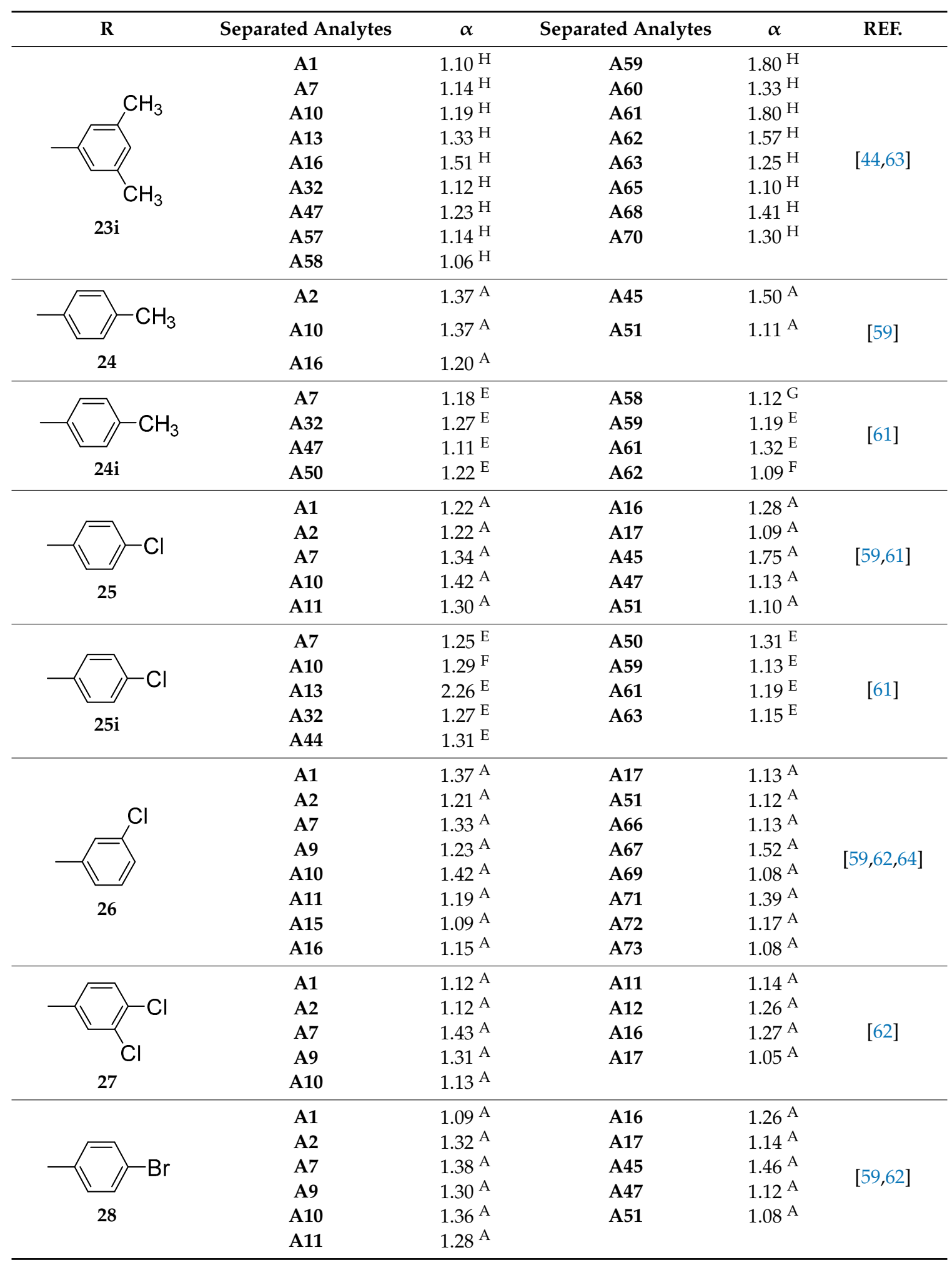


Table 2. Cont.

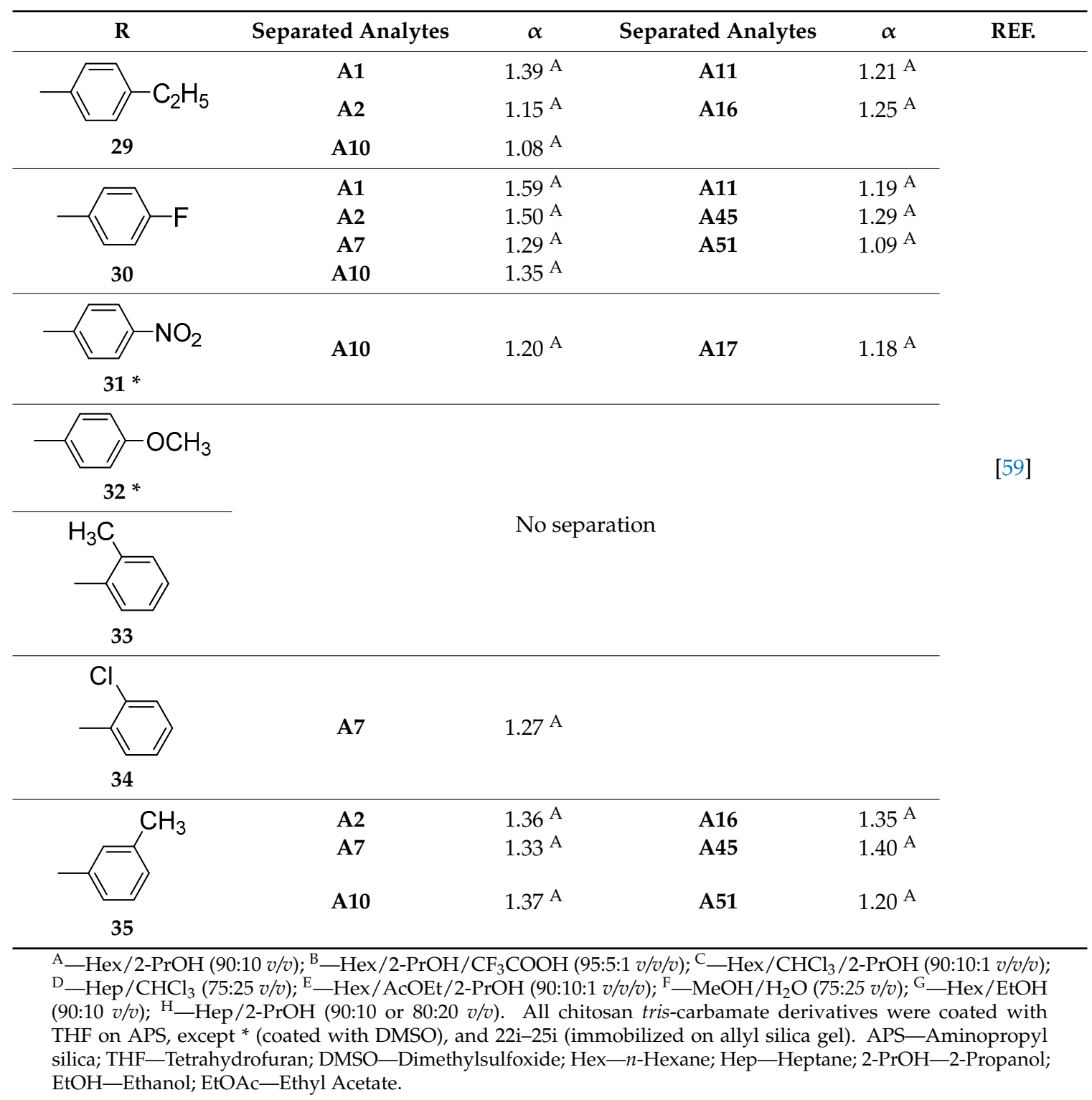

In 1998, the same group compared the chiral recognition performance of 3,5-dichloro- and 3,5-dimethylphenylcarbamate derivatives of several polysaccharides, including chitosan $(\mathbf{2 2}, \mathbf{2 3})$ (Table 2) [60]. These two chitosan derivatives presented a relatively high chiral recognition for the tested racemates, setting their potential use as CSPs [60]. In the same year, Franco et al., described another strategy to obtain new chitosan-based CSPs by bonding the chitin-carbamate derivatives on chromatographic support [44]. The obtained bonded CSPs allowed the use of a larger panel of solvents in the mobile phases compared to coated ones. Accordingly, the 3,5-dimethylphenylcarbamate derivative of chitosan (23i) was mixed with 10-undecenoyl and covalently immobilized on allyl silica gel, which demonstrate to be very useful in the separation of several racemates, such as lormetazepam and temazepam with a $\alpha$ value of 1.80 (Table 2). The mobile phases comprising either different proportions of heptane/2-propanol and heptane/chloroform mixtures allowed the best enantioresolutions [44]. 
Other mixed 10-undecenoyl/phenylcarbamate (22i) or benzoyl derivatives of chitosan (24i-25i), comprising different substituents in the aromatic ring, were prepared and immobilized on allyl silica gel (Table 2) [61]. Among the chitosan derivatives, the 3,5-dichlorophenylcarbamate derivative (22i) was found to have the most significant chiral discrimination ability.

In another study, the synthesis and chromatographic evaluation of the chitosan derivatives 22 and 23 as well as four new chitosan derivatives (25-28) were described (Table 2) [62]. All derivatives were coated on macroporous silica gel and evaluated as CSPs. Among them, the 3,5-dichloro- (22), 3,5-dimethyl- (23), and 3,4-dichlorophenylcarbamate (27) derivatives showed the best enantioseparation results for the tested racemates. The chiral recognition of the CSP based on the latter chitosan derivative (27) was investigated using chloroform as a component of the mobile phase, and some racemates were better resolved, including trans-stilbene oxide, trans-cyclopropanedicarboxylic acid and 1,2,2,2-tetraphenylethanol, with $\alpha$ values of $1.43,1.38$ and 1.31, respectively.

Another group described a study focused on the enantioresolution ability of the tris-3-chlorophenylcarbamate of chitosan (26) using various mobile phases [64]. They demonstrated that, in general, the alcohol used as organic modifier in the mobile phase greatly influenced the enantioseparation performance of the CSP. Baseline separations or near-baseline separations were achieved for benzoin $(\alpha=1.42)$, penconazole $(\alpha=1.52)$, hexaconazole $(\alpha=1.39)$ and epoxiconazole $(\alpha=1.36)$, whereas the other racemates were partially separated (Table 2) [64].

Zhang et al., also evaluated the enantioresolution of fourteen derivatives (21-26, 28-35) (Table 2) and concluded that like chitin phenylcarbamates [55], the nature of substituents and their position in the phenyl moiety, played a great role in the enantiorecognition of the derivative [59]. In fact, the 3,5-disubstituted phenylcarbamates of chitosan (22-23) CSPs have the highest chiral recognition abilities while 2-substituted phenylcarbamate (24-26, 28-35) CSPs showed the lowest enantiorecognition. Additionally, mobile phases containing ethyl acetate and chloroform were studied and, once again, revealed to improve the enantiorecognition performance of the CSPs [59].

To our knowledge, the most recent study with chitosan tris-phenylcarbamates was published by Guntari et al., in 2014 [63]. In this study, they developed and evaluated a new way of immobilization of chitosan tris-3,5-dimethylphenylcarbamate (23) using continuous assembly of polymers techniques. These techniques employed a catalyst immobilized on silica particles to produce stable CSPs suitable to be used in a wide range of mobile phases. The obtained CSP proved to be effective in separating the enantiomers of Trögers base and trans-stilbene oxide [63].

\subsubsection{Chitosan Bis-Carbamate CSPs}

The first study related to bis-carbamate derivatives as chiral selectors for LC was described by Son et al., in 2006, which reported the development of a CSP based on chitosan bis-3,5-dimethylphenylcarbamate in which the amine group of the chitosan was modified with $\mathrm{N}$-nicotinoyl-L-phenylalanine (36) (Table 3) [65]. The bis-phenylcarbamate derivative 36 demonstrated a high solubility in several organic solvents and, consequently, was easily coated on aminopropyl silica. The LC performance of the obtained CSP was evaluated using different mobile phases and all the tested racemates were enantioseparated. The best chromatographic result was achieved for flavanone with $\alpha$ and Rs values of 4.70 and 4.33, respectively, using a mixture of hexane/2-propanol 80:20 as mobile phase [65].

In 2008, Yamamoto et al., prepared several bis-carbamate derivatives with the amino group of chitosan replaced by an imide moiety (37-45) (Table 4) [62]. This study showed interesting results of enantioresolution for all the CSPs based on imide-chitosan derivatives. Examples include the resolution of trans-cyclopropanedicarboxylic acid dianilide in CSPs 42 and 45 with $\alpha$ values of 1.78 and 1.63 respectively, and the resolution of cobalt(III) tris (acetylacetonate) in CSP 41 with a $\alpha$ value of 1.84 . 
Table 3. Chitosan bis-carbamate CSP with the amine group of the chitosan modified by $N$-nicotinoyl-L-phenylalanine.

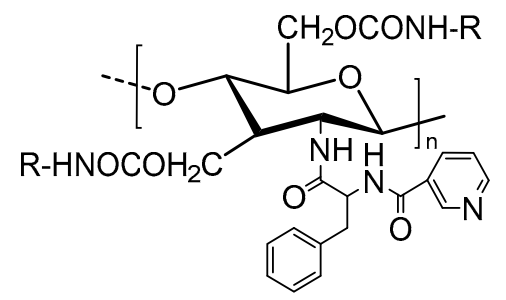

\begin{tabular}{cccccc}
\hline Structure & Separated Analytes & $\alpha$ & Separated Analytes & $\alpha$ & \multicolumn{1}{c}{ Ref. } \\
\hline & $\mathbf{A 1}$ & $1.54^{\mathrm{B}}$ & $\mathbf{A 1 0}$ & $2.05^{\mathrm{D}}$ & \\
& $\mathbf{A 2}$ & $4.70^{\mathrm{C}}$ & $\mathbf{A 1 1}$ & $2.19^{\mathrm{A}}$ & \\
& $\mathbf{A 7}$ & $4.28^{\mathrm{A}}$ & $\mathbf{A 1 2}$ & $2.76^{\mathrm{E}}$ & {$[65]$} \\
& $\mathbf{A 8}$ & $1.21^{\mathrm{A}}$ & $\mathbf{A 1 3}$ & $1.95^{\mathrm{E}}$ & \\
& $\mathbf{A}$ & $1.72^{\mathrm{D}}$ & $\mathbf{A 1 4}$ & $2.02^{\mathrm{E}}$ &
\end{tabular}

A_- Hex/2-PrOH (60:40 v/v); ${ }^{\mathrm{B}}-\mathrm{Hex} / 2-\mathrm{PrOH}(75: 25 v / v) ;{ }^{\mathrm{C}}$ - $\mathrm{Hex} / 2-\mathrm{PrOH}(80: 20 v / v) ;{ }^{\mathrm{D}} \_\mathrm{Hex} / 2-\mathrm{PrOH} / \mathrm{TFA}$ (95:5:0.2 v/v/v); $\quad \mathrm{E}_{-}-\mathrm{Hex} / \mathrm{CHCl}_{3} \quad(25: 75 \mathrm{v} / \mathrm{v})$. Coated with THF on APS. APS-Aminopropyl silica; THF-Tetrahydrofuran; DMSO-Dimethylsulfoxide; Hex-n-Hexane; 2-PrOH-2-Propanol; TFA-Trifluoroacetic acid.

In recent studies (2016), Tang et al., prepared several bis-phenylcarbamate derivatives in which the amine moiety of chitosan was modified by an isobutyrylamide moiety $(46-57)[66,67]$. The synthesized chitosan derivatives were coated on aminopropyl silica resulting in a series of new CSPs for LC. Considering their poor solubility, they were able to withstand operations with other mobile phases than the typical hexane/2-propanol (Table 5). They demonstrated high solvent tolerance and could still work after being flushed with chloroform $(100 \%)$, ethyl acetate $(100 \%)$ or tetrahydrofuran $/ n$-hexane $(70: 30 v / v)$ without significant loss of enantioseparation. Furthermore, the CSPs presented chiral recognition performance for some of the tested racemates, including Troger's base in CSPs 47, 49, 50, 55 and 57, with $\alpha$ values of 1.40,1.46, 1.54, 1.53 and 1.30 respectively, using $n$-hexane/2-propanol $(90 / 10 v / v)$ as mobile phase (Table 5) $[66,67]$.

Table 4. Chitosan bis-carbamate CSPs with the amine group of the chitosan replaced by an imide moiety.

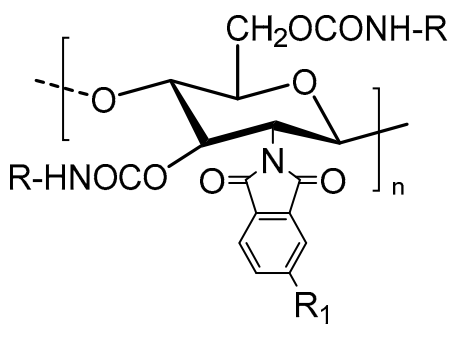

\begin{tabular}{|c|c|c|c|c|c|}
\hline Structure & Separated Analytes & $\alpha$ & Separated Analytes & $\alpha$ & Ref. \\
\hline & A1 & 1.23 & A11 & 1.12 & \\
\hline & A2 & 1.27 & A15 & 1.27 & [62] \\
\hline $\begin{array}{c}\mathrm{Cl} \\
\mathrm{R}_{1}=\mathrm{H} \\
37\end{array}$ & A9 & 1.19 & A16 & 1.12 & \\
\hline
\end{tabular}


Table 4. Cont.

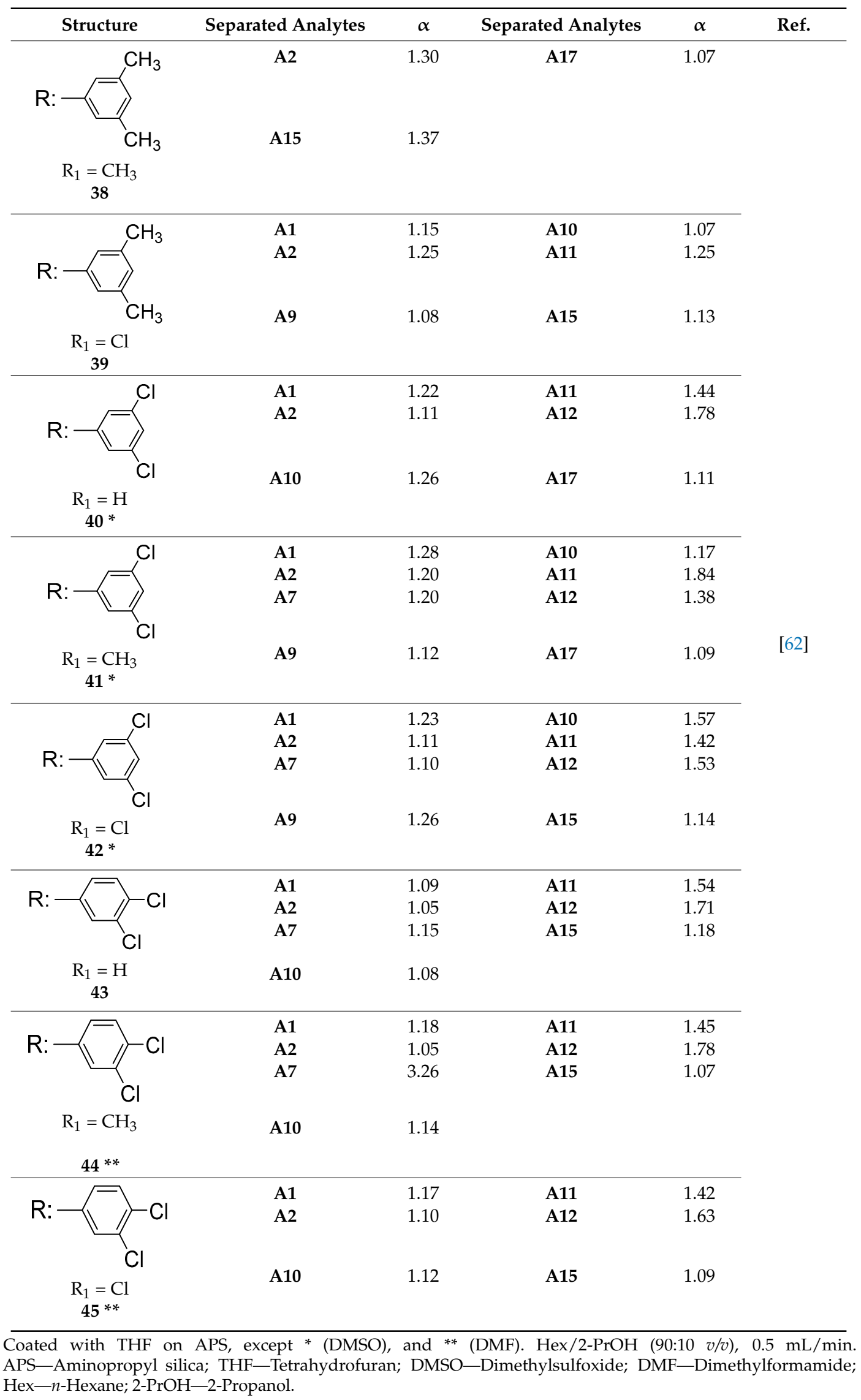


Table 5. Chitosan bis-carbamate CSPs with the amine moiety of chitosan modified by an alkylamide moiety.

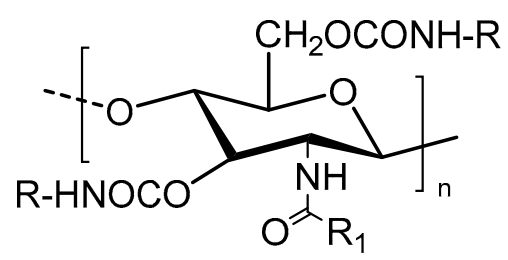

\begin{tabular}{|c|c|c|c|c|c|}
\hline Structure & Separated Analytes & $\alpha$ & Separated Analytes & $\alpha$ & REF. \\
\hline \multirow{9}{*}{$\mathrm{R}:-\mathrm{CH}_{3}$} & A1 & $1.36^{\mathrm{B}}$ & A20 & $1.16^{\mathrm{A}}$ & \multirow{9}{*}[66,68]{} \\
\hline & A2 & $1.29^{\mathrm{B}}$ & A21 & $1.28^{\mathrm{A}}$ & \\
\hline & A3 & $1.07^{\mathrm{B}}$ & A22 & $1.17^{\mathrm{A}}$ & \\
\hline & A4 & $1.22^{\mathrm{B}}$ & A23 & $1.12^{\mathrm{C}}$ & \\
\hline & A5 & $1.12^{\mathrm{A}}$ & A24 & $1.10^{\mathrm{A}}$ & \\
\hline & A6 & $1.31^{\mathrm{B}}$ & A25 & $1.11^{\mathrm{A}}$ & \\
\hline & A10 & $1.08^{\mathrm{A}}$ & A26 & $1.26^{\mathrm{A}}$ & \\
\hline & A18 & $1.30^{\mathrm{B}}$ & A27 & $1.05^{\mathrm{A}}$ & \\
\hline & A19 & $1.26^{\mathrm{B}}$ & A28 & $2.64^{\mathrm{A}}$ & \\
\hline \multirow{10}{*}{$\mathrm{R}_{1}=\underset{47}{\mathrm{CH}\left(\mathrm{CH}_{3}\right)_{2}}$} & A1 & $1.40^{\mathrm{A}}$ & A21 & $1.42^{\mathrm{A}}$ & \multirow{28}{*}[66]{} \\
\hline & A2 & $1.36^{\mathrm{A}}$ & A22 & $1.21^{\mathrm{A}}$ & \\
\hline & A3 & $1.06^{\mathrm{B}}$ & A23 & $1.20^{\mathrm{B}}$ & \\
\hline & A4 & $1.15^{\mathrm{A}}$ & A24 & $1.23^{\mathrm{A}}$ & \\
\hline & A5 & $1.08^{\mathrm{A}}$ & A25 & $1.17^{\mathrm{A}}$ & \\
\hline & A6 & $1.44^{\mathrm{A}}$ & A26 & $1.52^{\mathrm{A}}$ & \\
\hline & A10 & $1.11^{\mathrm{C}}$ & A27 & $1.19^{\mathrm{A}}$ & \\
\hline & A18 & $1.34^{\mathrm{A}}$ & A36 & $1.05^{\mathrm{A}}$ & \\
\hline & A19 & $1.53^{\mathrm{A}}$ & A28 & $3.28^{\mathrm{A}}$ & \\
\hline & A20 & $1.15^{\mathrm{A}}$ & & & \\
\hline \multirow{10}{*}{$\mathrm{R}: \underbrace{\mathrm{CH}\left(\mathrm{CH}_{3}\right)_{2}}_{\mathrm{Cl}}$} & A1 & $1.24^{\mathrm{B}}$ & A21 & $1.59^{\mathrm{A}}$ & \\
\hline & A2 & $1.47^{\mathrm{A}}$ & A22 & $1.08^{\mathrm{A}}$ & \\
\hline & A3 & $1.09^{C}$ & A23 & $1.05^{\mathrm{A}}$ & \\
\hline & A4 & $1.31^{\mathrm{C}}$ & A24 & $1.16^{\mathrm{A}}$ & \\
\hline & A5 & $1.18^{\mathrm{C}}$ & A25 & $1.13^{\mathrm{A}}$ & \\
\hline & A6 & $1.22^{C}$ & A26 & $1.09^{\mathrm{A}}$ & \\
\hline & A10 & $1.05^{\mathrm{C}}$ & A27 & $1.29^{C}$ & \\
\hline & A18 & $1.90 \mathrm{~A}$ & A28 & $4.32^{\mathrm{A}}$ & \\
\hline & A19 & $1.73^{\mathrm{A}}$ & A36 & $1.22^{\mathrm{A}}$ & \\
\hline & A20 & $1.20^{\mathrm{A}}$ & A20 & $1.25^{\mathrm{A}}$ & \\
\hline \multirow{8}{*}{$\begin{array}{c}\mathrm{R}: \longrightarrow \\
\mathrm{R}_{1}=\underset{49}{\mathrm{CH}\left(\mathrm{CH}_{3}\right)_{2}}\end{array}$} & A1 & $1.46^{\mathrm{A}}$ & & & \\
\hline & A2 & $1.26^{\mathrm{C}}$ & A21 & $1.36^{\mathrm{B}}$ & \\
\hline & A3 & $1.06^{\mathrm{B}}$ & A22 & $1.14^{\mathrm{C}}$ & \\
\hline & A4 & $1.23^{C}$ & A23 & $1.13^{C}$ & \\
\hline & A5 & $1.12^{\mathrm{A}}$ & A25 & $1.05^{\mathrm{A}}$ & \\
\hline & A10 & $1.08^{\mathrm{C}}$ & A26 & $1.16^{\mathrm{B}}$ & \\
\hline & A18 & $1.54^{\mathrm{A}}$ & A27 & $1.14^{\mathrm{B}}$ & \\
\hline & A19 & $1.24^{\mathrm{A}}$ & A28 & $1.59^{\mathrm{A}}$ & \\
\hline \multirow{10}{*}{$\begin{array}{c}\mathrm{R}: \longrightarrow \\
\mathrm{R}_{1}=\underset{\mathbf{5 0}}{\mathrm{CH}\left(\mathrm{CH}_{3}\right)_{2}}\end{array}$} & A1 & $1.54^{\mathrm{A}}$ & A21 & $1.45^{\mathrm{A}}$ & \multirow{10}{*}[66,69]{} \\
\hline & A2 & $1.35^{\mathrm{C}}$ & A22 & $1.19^{\mathrm{C}}$ & \\
\hline & A3 & $1.03^{\mathrm{B}}$ & A23 & $1.19^{C}$ & \\
\hline & A4 & $1.23^{C}$ & A24 & $1.15^{\mathrm{A}}$ & \\
\hline & A5 & $1.12^{\mathrm{A}}$ & A25 & $1.15^{\mathrm{A}}$ & \\
\hline & A6 & $1.20^{\mathrm{A}}$ & A26 & $1.20^{\mathrm{B}}$ & \\
\hline & A10 & $1.10^{C}$ & A27 & $1.16^{\mathrm{B}}$ & \\
\hline & A18 & $1.57^{\mathrm{A}}$ & A28 & $2.12^{\mathrm{A}}$ & \\
\hline & A19 & $1.35^{\mathrm{A}}$ & A36 & $1.15^{\mathrm{B}}$ & \\
\hline & A20 & $1.20^{\mathrm{B}}$ & & & \\
\hline
\end{tabular}


Table 5. Cont.

\begin{tabular}{|c|c|c|c|c|c|}
\hline Structure & Separated Analytes & $\alpha$ & Separated Analytes & $\alpha$ & REF. \\
\hline \multirow{5}{*}{$\mathrm{R}: \longrightarrow$} & A1 & $1.14^{\mathrm{B}}$ & A25 & $1.09^{\mathrm{C}}$ & \multirow{5}{*}{ [66] } \\
\hline & A2 & $1.08^{\mathrm{B}}$ & A26 & $1.24^{\mathrm{B}}$ & \\
\hline & A5 & $1.05^{\mathrm{A}}$ & A27 & $1.10^{\mathrm{C}}$ & \\
\hline & A6 & $1.32^{\mathrm{A}}$ & A28 & $3.57^{\mathrm{A}}$ & \\
\hline & A10 & $1.14^{\mathrm{B}}$ & & & \\
\hline \multirow{10}{*}{ 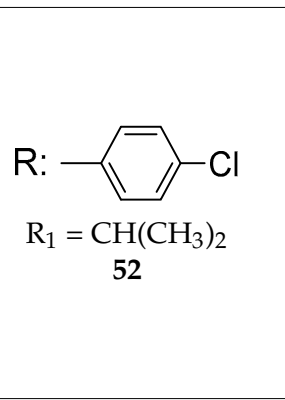 } & A1 & $1.15^{\mathrm{B}}$ & A21 & $1.45^{\mathrm{A}}$ & \multirow{10}{*}{ [67] } \\
\hline & A2 & $1.25^{\mathrm{A}}$ & A22 & $1.45^{\mathrm{B}}$ & \\
\hline & A3 & $1.14^{\mathrm{C}}$ & A23 & $1.45^{\mathrm{B}}$ & \\
\hline & A4 & $1.14^{\mathrm{A}}$ & A24 & $1.38^{\mathrm{A}}$ & \\
\hline & A5 & $1.11^{\mathrm{C}}$ & A25 & $1.04^{\mathrm{A}}$ & \\
\hline & A6 & $1.25^{\mathrm{B}}$ & A26 & $1.20^{\mathrm{C}}$ & \\
\hline & A10 & $1.06^{\mathrm{A}}$ & A27 & $1.14^{\mathrm{B}}$ & \\
\hline & A18 & $1.74^{\mathrm{A}}$ & A28 & $2.17^{\mathrm{A}}$ & \\
\hline & A19 & $1.22^{\mathrm{A}}$ & A36 & $1.11^{\mathrm{A}}$ & \\
\hline & A20 & $1.07^{\mathrm{A}}$ & & & \\
\hline \multirow{7}{*}{$\mathrm{R}:$} & A1 & $1.12^{\mathrm{B}}$ & A20 & $1.45^{\mathrm{A}}$ & \multirow{38}{*}{ [67] } \\
\hline & A2 & $1.24^{\mathrm{A}}$ & A21 & $1.42^{\mathrm{A}}$ & \\
\hline & A4 & $1.24^{\mathrm{A}}$ & A25 & $1.14^{\mathrm{B}}$ & \\
\hline & A6 & $1.09^{\mathrm{B}}$ & A27 & $1.16^{\mathrm{B}}$ & \\
\hline & A10 & $1.39^{\mathrm{A}}$ & A28 & $2.40^{\mathrm{A}}$ & \\
\hline & A18 & $1.39^{\mathrm{A}}$ & A36 & $1.14^{\mathrm{A}}$ & \\
\hline & A19 & $1.56^{\mathrm{A}}$ & & & \\
\hline \multirow{9}{*}{$\mathrm{R}_{1}=\underset{\mathbf{C H}}{\mathrm{CH}\left(\mathrm{CH}_{3}\right)_{2}}$} & A1 & $1.53^{\mathrm{A}}$ & A20 & $1.31^{\mathrm{A}}$ & \\
\hline & A2 & $1.36^{\mathrm{A}}$ & A21 & $1.56^{\mathrm{A}}$ & \\
\hline & A3 & $1.05^{\mathrm{A}}$ & A22 & $1.11^{\mathrm{B}}$ & \\
\hline & A4 & $1.44^{\mathrm{A}}$ & A23 & $1.12^{\mathrm{B}}$ & \\
\hline & A5 & $1.18^{\mathrm{A}}$ & A24 & $1.05^{\mathrm{A}}$ & \\
\hline & A6 & $1.22^{\mathrm{B}}$ & A27 & $1.14^{\mathrm{C}}$ & \\
\hline & A10 & $1.14^{\mathrm{C}}$ & A28 & $1.81^{\mathrm{B}}$ & \\
\hline & A18 & $1.74^{\mathrm{A}}$ & A36 & $1.27^{\mathrm{A}}$ & \\
\hline & A19 & $1.53^{\mathrm{A}}$ & & & \\
\hline \multirow{7}{*}{$\mathrm{R}: \underbrace{\mathrm{CH}\left(\mathrm{CH}_{3}\right)_{2}}_{\mathrm{CF}_{3}}$} & A1 & $1.53^{\mathrm{A}}$ & A20 & $1.56^{\mathrm{A}}$ & \\
\hline & A2 & $1.17^{\mathrm{A}}$ & A21 & $1.25^{\mathrm{A}}$ & \\
\hline & A4 & $1.29^{B}$ & A22 & $1.10^{\mathrm{C}}$ & \\
\hline & A6 & $1.29^{\mathrm{A}}$ & A23 & $1.10^{C}$ & \\
\hline & A10 & $1.15^{\mathrm{A}}$ & A27 & $1.11^{\mathrm{B}}$ & \\
\hline & A18 & $1.50^{\mathrm{A}}$ & A28 & $1.61^{\mathrm{A}}$ & \\
\hline & A19 & $1.12^{\mathrm{B}}$ & A36 & $1.26^{\mathrm{A}}$ & \\
\hline \multirow{7}{*}{$\mathrm{R}_{1}=\underset{56}{\mathrm{CH}\left(\mathrm{CH}_{3}\right)_{2}}$} & A1 & $1.21^{\mathrm{A}}$ & A20 & $1.20^{\mathrm{A}}$ & \\
\hline & A2 & $1.28^{\mathrm{A}}$ & A21 & $1.17^{\mathrm{A}}$ & \\
\hline & A4 & $1.34^{\mathrm{A}}$ & A22 & $1.15^{\mathrm{A}}$ & \\
\hline & A6 & $1.14^{\mathrm{C}}$ & A23 & $1.15^{\mathrm{A}}$ & \\
\hline & A10 & $1.24^{\mathrm{B}}$ & A27 & $1.55^{\mathrm{B}}$ & \\
\hline & A18 & $1.15^{\mathrm{A}}$ & A28 & $2.26^{\mathrm{A}}$ & \\
\hline & A19 & $1.21^{\mathrm{B}}$ & & & \\
\hline \multirow{8}{*}{$\mathrm{R}:-\underset{\mathbf{R}}{\mathrm{R}}=\underset{\mathrm{CH}\left(\mathrm{CH}_{3}\right)_{2}}{-\mathrm{OCF}_{3}}$} & A1 & $1.30^{C}$ & A21 & $1.34^{\mathrm{A}}$ & \\
\hline & A2 & $1.50^{\mathrm{B}}$ & A22 & $1.13^{C}$ & \\
\hline & A4 & $1.83^{\mathrm{B}}$ & A23 & $1.13^{C}$ & \\
\hline & A6 & $1.11^{\mathrm{A}}$ & A25 & $1.15^{\mathrm{A}}$ & \\
\hline & A10 & $1.27^{C}$ & A26 & $1.17^{\mathrm{A}}$ & \\
\hline & A18 & $1.19^{\mathrm{A}}$ & A27 & $1.19^{\mathrm{A}}$ & \\
\hline & A19 & $1.36^{\mathrm{B}}$ & A28 & $2.94^{\mathrm{A}}$ & \\
\hline & A20 & $1.07^{\mathrm{A}}$ & A36 & $1.07^{\mathrm{C}}$ & \\
\hline
\end{tabular}


Table 5. Cont.

\begin{tabular}{|c|c|c|c|c|c|}
\hline Structure & Separated Analytes & $\alpha$ & Separated Analytes & $\alpha$ & REF. \\
\hline \multirow{10}{*}{$\mathrm{R}: \underbrace{}_{\substack{\mathrm{R}_{1} \\
=\mathrm{C}_{3} \mathrm{H}_{5}}}$} & A1 & $1.30^{\mathrm{B}}$ & A23 & $1.11^{\mathrm{B}}$ & \multirow{35}{*}{ [69] } \\
\hline & A2 & $1.71^{\mathrm{B}}$ & A24 & $1.06^{\mathrm{A}}$ & \\
\hline & A4 & $1.14^{\mathrm{A}}$ & A25 & $1.48^{\mathrm{A}}$ & \\
\hline & A5 & $1.05^{\mathrm{A}}$ & A26 & $1.09^{\mathrm{B}}$ & \\
\hline & A6 & $1.32^{\mathrm{C}}$ & A27 & $1.11^{\mathrm{B}}$ & \\
\hline & A10 & $1.16^{\mathrm{B}}$ & A28 & $3.15^{\mathrm{A}}$ & \\
\hline & A18 & $2.09^{\mathrm{A}}$ & A36 & $1.14^{\mathrm{A}}$ & \\
\hline & A19 & $1.55^{\mathrm{A}}$ & A49 & $1.06^{\mathrm{A}}$ & \\
\hline & A20 & $1.27^{\mathrm{A}}$ & A54 & $1.07^{\mathrm{A}}$ & \\
\hline & A21 & $2.02^{\mathrm{A}}$ & & & \\
\hline \multirow{9}{*}{$\mathrm{R}: \underbrace{\mathrm{C}_{5} \mathrm{H}_{9}}_{\mathrm{Cl}}$} & A1 & $1.69^{C}$ & A23 & $1.15^{\mathrm{B}}$ & \\
\hline & A2 & $1.45^{\mathrm{B}}$ & A24 & $1.08^{\mathrm{A}}$ & \\
\hline & A4 & $1.34^{\mathrm{C}}$ & A25 & $1.10^{\mathrm{C}}$ & \\
\hline & A6 & $1.53^{\mathrm{B}}$ & A26 & $1.07^{\mathrm{C}}$ & \\
\hline & A10 & $1.26^{\mathrm{A}}$ & A28 & $1.63^{\mathrm{B}}$ & \\
\hline & A18 & $2.43^{\mathrm{A}}$ & A36 & $1.27^{\mathrm{A}}$ & \\
\hline & A19 & $1.47^{\mathrm{B}}$ & A49 & $1.07^{\mathrm{A}}$ & \\
\hline & A20 & $1.35^{\mathrm{A}}$ & A54 & $1.06^{\mathrm{A}}$ & \\
\hline & A21 & $2.28^{\mathrm{A}}$ & & & \\
\hline \multirow{8}{*}{$\mathrm{R}:-\underset{\mathbf{6 0}}{\left.\mathrm{R}_{1}=\mathrm{CH}_{2}\right)_{2} \mathrm{CH}_{3}}$} & A1 & $1.90^{\mathrm{A}}$ & A21 & $2.11^{\mathrm{B}}$ & \\
\hline & A2 & $1.67^{\mathrm{A}}$ & A23 & $1.10^{C}$ & \\
\hline & A4 & $1.35^{\mathrm{B}}$ & A24 & $1.28^{\mathrm{A}}$ & \\
\hline & A6 & $1.54^{\mathrm{A}}$ & A25 & $1.14^{\mathrm{A}}$ & \\
\hline & A10 & $1.08^{\mathrm{B}}$ & A26 & $1.15^{\mathrm{B}}$ & \\
\hline & A18 & $2.24^{\mathrm{A}}$ & A27 & $1.25^{C}$ & \\
\hline & A19 & $1.66^{\mathrm{A}}$ & A28 & $3.03^{C}$ & \\
\hline & A20 & $1.46^{\mathrm{A}}$ & A49 & $1.34^{\mathrm{B}}$ & \\
\hline \multirow{8}{*}{$\mathrm{R}:-\underset{\mathbf{6 1}}{\mathrm{R}_{1}=\underset{\left(\mathrm{CH}_{2}\right)_{4} \mathrm{CH}_{3}}{-}}$} & A1 & $1.54^{\mathrm{B}}$ & A21 & $3.47^{\mathrm{A}}$ & \\
\hline & A2 & $1.45^{\mathrm{A}}$ & A24 & $1.11^{\mathrm{C}}$ & \\
\hline & A4 & $1.19^{C}$ & A25 & $1.14^{\mathrm{A}}$ & \\
\hline & A6 & $1.28^{\mathrm{A}}$ & A26 & $1.16^{\mathrm{B}}$ & \\
\hline & A10 & $1.04^{C}$ & A27 & $1.44^{\mathrm{B}}$ & \\
\hline & A18 & $2.42^{\mathrm{A}}$ & A28 & $3.57^{\mathrm{B}}$ & \\
\hline & A19 & $1.10^{\mathrm{C}}$ & A36 & $1.13^{C}$ & \\
\hline & A20 & $1.47^{\mathrm{A}}$ & A49 & $1.34^{\mathrm{A}}$ & \\
\hline \multirow{7}{*}{$\mathrm{R}:-\underbrace{}_{\mathbf{6}}=\underset{\mathrm{R}_{1}}{\mathrm{CH}_{2} \mathrm{CH}_{3}}$} & A1 & $1.09^{\mathrm{A}}$ & A27 & $1.16^{\mathrm{C}}$ & \multirow{18}{*}{ [68] } \\
\hline & A2 & $1.29^{\mathrm{B}}$ & A28 & $1.24^{\mathrm{C}}$ & \\
\hline & A4 & $1.14^{\mathrm{C}}$ & A29 & $1.11^{\mathrm{A}}$ & \\
\hline & A10 & $1.12^{\mathrm{B}}$ & A38 & $1.58^{\mathrm{B}}$ & \\
\hline & A19 & $1.48^{\mathrm{A}}$ & A47 & $1.13^{\mathrm{A}}$ & \\
\hline & A21 & $1.04^{\mathrm{C}}$ & A55 & $1.18^{\mathrm{A}}$ & \\
\hline & A25 & $1.58^{\mathrm{A}}$ & & & \\
\hline \multirow{5}{*}{$\mathrm{R}:-\mathrm{CH}_{3}$} & A2 & $1.21^{\mathrm{A}}$ & A21 & $1.32^{\mathrm{A}}$ & \\
\hline & A4 & $1.14^{\mathrm{A}}$ & A25 & $1.12^{\mathrm{A}}$ & \\
\hline & A18 & $1.52^{\mathrm{A}}$ & A28 & $1.91^{\mathrm{A}}$ & \\
\hline & A19 & $1.10^{\mathrm{A}}$ & A30 & $1.21^{\mathrm{A}}$ & \\
\hline & A20 & $1.14^{\mathrm{A}}$ & A47 & $1.07^{\mathrm{A}}$ & \\
\hline \multirow{6}{*}{$\mathrm{R}:-\underbrace{}_{\mathbf{6}}=\mathrm{R}_{\mathbf{6}}=\mathrm{CH}_{3}$} & A2 & $1.15^{\mathrm{A}}$ & A20 & $1.17^{\mathrm{A}}$ & \\
\hline & A4 & $1.05^{\mathrm{A}}$ & A21 & $1.18^{\mathrm{A}}$ & \\
\hline & A6 & $1.07^{\mathrm{A}}$ & A27 & $1.09^{\mathrm{A}}$ & \\
\hline & A10 & $1.09^{\mathrm{A}}$ & A28 & $1.36^{\mathrm{A}}$ & \\
\hline & A18 & $1.31^{\mathrm{A}}$ & A29 & $1.06^{\mathrm{A}}$ & \\
\hline & A19 & $1.20^{\mathrm{B}}$ & A30 & $1.20^{\mathrm{B}}$ & \\
\hline
\end{tabular}


Table 5. Cont.

\begin{tabular}{|c|c|c|c|c|c|}
\hline Structure & Separated Analytes & $\alpha$ & Separated Analytes & $\alpha$ & REF. \\
\hline \multirow{8}{*}{$\mathrm{R}: \underbrace{}_{\substack{\mathrm{R}_{1}=\mathrm{C}_{4} \mathrm{H}_{7} \\
65}}-\mathrm{C}$} & A1 & $1.25^{\mathrm{B}}$ & A20 & $1.16^{\mathrm{A}}$ & \multirow{57}{*}{ [70] } \\
\hline & A2 & $1.36^{\mathrm{B}}$ & A21 & $1.37^{\mathrm{A}}$ & \\
\hline & A3 & $1.09^{B}$ & A22 & $1.15^{\mathrm{C}}$ & \\
\hline & A4 & $1.29 \mathrm{~A}$ & A25 & $1.13^{\mathrm{A}}$ & \\
\hline & A6 & $1.99 \mathrm{~A}$ & A26 & $1.18^{\mathrm{C}}$ & \\
\hline & A10 & $1.10^{\mathrm{A}}$ & A27 & $1.02^{\mathrm{C}}$ & \\
\hline & A18 & $1.37^{\mathrm{A}}$ & A28 & $3.91^{\mathrm{B}}$ & \\
\hline & A19 & $1.47^{\mathrm{A}}$ & A49 & $1.12^{\mathrm{A}}$ & \\
\hline \multirow{9}{*}{$\mathrm{R:C}$} & A1 & $1.56^{\mathrm{B}}$ & A21 & $2.03^{\mathrm{A}}$ & \\
\hline & A2 & $1.41^{\mathrm{A}}$ & $\mathrm{A} 22$ & $1.13^{\mathrm{C}}$ & \\
\hline & A3 & $1.11^{\mathrm{A}}$ & A24 & $1.14^{\mathrm{A}}$ & \\
\hline & A4 & $1.45^{\mathrm{B}}$ & A25 & $1.07^{\mathrm{C}}$ & \\
\hline & A6 & $1.35^{\mathrm{B}}$ & A26 & $1.22^{\mathrm{C}}$ & \\
\hline & A10 & $1.16^{\mathrm{C}}$ & A27 & $1.11^{\mathrm{C}}$ & \\
\hline & A18 & $1.77^{\mathrm{A}}$ & A28 & $4.51^{\mathrm{B}}$ & \\
\hline & A19 & $1.84^{\mathrm{A}}$ & A36 & $1.19^{\mathrm{A}}$ & \\
\hline & A20 & $1.28^{\mathrm{A}}$ & A49 & $1.28^{\mathrm{A}}$ & \\
\hline \multirow{9}{*}{$\mathrm{R}: \underbrace{-\mathrm{Cl}}_{\substack{\mathrm{R}_{1}=\mathrm{C}_{4} \mathrm{H}_{7} \\
\mathbf{6 7}}}$} & A1 & $1.53^{\mathrm{B}}$ & A21 & $1.90^{\mathrm{A}}$ & \\
\hline & A2 & $1.53^{C}$ & A22 & $1.12^{\mathrm{C}}$ & \\
\hline & A3 & $1.09 \mathrm{~A}$ & A25 & $1.22^{\mathrm{A}}$ & \\
\hline & A4 & $1.66^{\mathrm{A}}$ & A26 & $1.08^{\mathrm{C}}$ & \\
\hline & A6 & $1.37^{\mathrm{B}}$ & A27 & $1.08^{\mathrm{C}}$ & \\
\hline & A10 & $1.10^{\mathrm{A}}$ & A28 & $3.46^{\mathrm{B}}$ & \\
\hline & A18 & $1.62^{\mathrm{A}}$ & A36 & $1.18^{\mathrm{A}}$ & \\
\hline & A19 & $1.61^{\mathrm{A}}$ & A49 & $1.21^{\mathrm{A}}$ & \\
\hline & A20 & $1.13^{\mathrm{A}}$ & & & \\
\hline & A2 & $1.57^{\mathrm{A}}$ & A24 & $1.27^{\mathrm{A}}$ & \\
\hline & A4 & $1.11^{\mathrm{B}}$ & A25 & $1.09^{\mathrm{A}}$ & \\
\hline & A6 & $1.41^{\mathrm{B}}$ & A26 & $1.18^{\mathrm{B}}$ & \\
\hline & A10 & $1.26^{\mathrm{B}}$ & A27 & $1.12^{\mathrm{C}}$ & \\
\hline & A18 & $1.21^{\mathrm{A}}$ & A28 & $8.64^{B}$ & \\
\hline & A19 & $1.76^{\mathrm{A}}$ & A36 & $1.17^{\mathrm{A}}$ & \\
\hline & A21 & $1.37^{\mathrm{A}}$ & A49 & $1.42^{\mathrm{C}}$ & \\
\hline & A22 & $1.21^{\mathrm{B}}$ & & & \\
\hline \multirow{9}{*}{$\begin{array}{c}\mathrm{R}: \longrightarrow \\
\mathrm{R}_{1}=\mathrm{C}_{4} \mathrm{H}_{7} \\
69\end{array}$} & A1 & $1.44^{\mathrm{B}}$ & A22 & $1.24^{\mathrm{C}}$ & \\
\hline & A2 & $1.41^{\mathrm{A}}$ & A24 & $1.17^{\mathrm{A}}$ & \\
\hline & A4 & $1.33^{\mathrm{A}}$ & A25 & $1.11^{\mathrm{A}}$ & \\
\hline & A6 & $1.74^{\mathrm{A}}$ & A26 & $1.13^{\mathrm{B}}$ & \\
\hline & A10 & $1.05^{\mathrm{A}}$ & A27 & $1.24^{\mathrm{A}}$ & \\
\hline & A18 & $1.45^{\mathrm{A}}$ & A28 & $3.78^{\mathrm{B}}$ & \\
\hline & A19 & $1.60^{\mathrm{A}}$ & A36 & $1.07^{\mathrm{B}}$ & \\
\hline & A20 & $1.26^{\mathrm{B}}$ & A49 & $1.28^{\mathrm{A}}$ & \\
\hline & A21 & $1.85^{\mathrm{A}}$ & & & \\
\hline \multirow{7}{*}{$\begin{array}{c}\mathrm{R}: \longrightarrow \\
\substack{\mathrm{R}_{1}=\mathrm{C}_{4} \mathrm{H}_{7} \\
\mathbf{7 0}}\end{array}$} & A1 & $1.31^{\mathrm{B}}$ & A21 & $1.46^{\mathrm{A}}$ & \\
\hline & A2 & $1.31^{\mathrm{B}}$ & A22 & $1.21^{\mathrm{B}}$ & \\
\hline & A4 & $1.32^{\mathrm{A}}$ & A26 & $1.04^{\mathrm{B}}$ & \\
\hline & A6 & $1.48^{\mathrm{A}}$ & A27 & $1.09^{\mathrm{B}}$ & \\
\hline & A18 & $1.42^{\mathrm{A}}$ & A28 & $2.68^{\mathrm{B}}$ & \\
\hline & A19 & $1.35^{\mathrm{A}}$ & A36 & $1.11^{\mathrm{C}}$ & \\
\hline & A20 & $1.23^{\mathrm{A}}$ & A49 & $1.20^{\mathrm{A}}$ & \\
\hline \multirow{7}{*}{$\mathrm{R}:{ }_{\substack{\mathrm{Cl} \\
\mathrm{R}_{1}}=\mathrm{C}_{4} \mathrm{H}_{7}}$} & A1 & $1.22^{\mathrm{B}}$ & A24 & $1.08^{\mathrm{A}}$ & \\
\hline & A2 & $1.18^{\mathrm{B}}$ & A26 & $1.03^{\mathrm{A}}$ & \\
\hline & A4 & $1.13^{\mathrm{A}}$ & A27 & $1.18^{\mathrm{A}}$ & \\
\hline & A6 & $1.29^{\mathrm{B}}$ & A28 & $3.16^{\mathrm{A}}$ & \\
\hline & A18 & $1.26^{\mathrm{A}}$ & A36 & $1.05^{\mathrm{A}}$ & \\
\hline & A19 & $1.29 \mathrm{~A}$ & A49 & $1.07^{\mathrm{A}}$ & \\
\hline & A21 & $1.25^{\mathrm{A}}$ & & & \\
\hline
\end{tabular}


Table 5. Cont.

\begin{tabular}{|c|c|c|c|c|c|}
\hline Structure & Separated Analytes & $\alpha$ & Separated Analytes & $\alpha$ & REF. \\
\hline \multirow{9}{*}{$\begin{array}{l}\mathrm{R}: \mathrm{CH}_{3} \\
\mathrm{R}_{1}=\left(\mathrm{CH}_{2}\right)_{3} \mathrm{CH}_{3}\end{array}$} & A1 & $1.64^{C}$ & A24 & $1.33^{\mathrm{A}}$ & \multirow{49}{*}{ [71] } \\
\hline & A2 & $1.71^{\mathrm{C}}$ & A25 & $1.08^{\mathrm{A}}$ & \\
\hline & A4 & $1.11^{\mathrm{C}}$ & A27 & $1.52^{\mathrm{B}}$ & \\
\hline & A6 & $1.50^{\mathrm{B}}$ & A28 & $4.53^{C}$ & \\
\hline & A10 & $1.12^{\mathrm{A}}$ & A29 & $1.07^{\mathrm{B}}$ & \\
\hline & A18 & $1.23^{\mathrm{A}}$ & A30 & $1.20^{\mathrm{B}}$ & \\
\hline & A19 & $1.58^{\mathrm{A}}$ & A47 & $2.70^{\mathrm{B}}$ & \\
\hline & A20 & $1.09^{\mathrm{B}}$ & A54 & $1.04^{\mathrm{A}}$ & \\
\hline & A21 & $1.74^{\mathrm{B}}$ & & & \\
\hline \multirow{8}{*}{$\mathrm{R}: \mathrm{R}_{\mathrm{Cl}}^{\left(\mathrm{CH}_{2}\right)_{3} \mathrm{CH}_{3}}$} & A1 & $2.15^{C}$ & A21 & $1.18^{\mathrm{C}}$ & \\
\hline & A2 & $1.66^{\mathrm{A}}$ & A25 & $1.18^{\mathrm{C}}$ & \\
\hline & A4 & $1.21^{\mathrm{C}}$ & A27 & $1.40^{\mathrm{B}}$ & \\
\hline & A6 & $1.08^{\mathrm{B}}$ & A28 & $4.12^{\mathrm{A}}$ & \\
\hline & A10 & $1.25^{\mathrm{A}}$ & A29 & $2.01^{\mathrm{A}}$ & \\
\hline & A18 & $3.14^{\mathrm{A}}$ & A30 & $1.19^{\mathrm{B}}$ & \\
\hline & A19 & $1.66^{\mathrm{A}}$ & A47 & $1.84^{\mathrm{B}}$ & \\
\hline & A20 & $1.35^{\mathrm{B}}$ & & & \\
\hline \multirow{8}{*}{$\mathrm{R}: \mathrm{Cl}_{\mathrm{Cl}}^{\left(\mathrm{CH}_{2}\right)_{3} \mathrm{CH}_{3}} \mathrm{Cl}$} & A1 & $1.44^{\mathrm{C}}$ & A21 & $1.97^{\mathrm{A}}$ & \\
\hline & A2 & $1.68^{\mathrm{A}}$ & A24 & $1.20^{\mathrm{A}}$ & \\
\hline & A4 & $1.37^{\mathrm{A}}$ & A25 & $1.13^{\mathrm{A}}$ & \\
\hline & A5 & $1.06^{\mathrm{A}}$ & A27 & $1.24^{\mathrm{B}}$ & \\
\hline & A10 & $1.15^{\mathrm{A}}$ & A28 & $4.31^{\mathrm{B}}$ & \\
\hline & A18 & $1.80^{\mathrm{A}}$ & A29 & $1.15^{\mathrm{B}}$ & \\
\hline & A19 & $1.81^{\mathrm{A}}$ & A30 & $1.13^{\mathrm{B}}$ & \\
\hline & A20 & $1.22^{\mathrm{A}}$ & A47 & $1.37^{\mathrm{A}}$ & \\
\hline \multirow{8}{*}{$\mathrm{R}: \longrightarrow \mathrm{R}_{\mathbf{R}}=\underset{75}{\left(\mathrm{CH}_{2}\right)_{3} \mathrm{CH}_{3}}$} & A1 & $2.07^{C}$ & A21 & $2.09^{\mathrm{A}}$ & \\
\hline & A2 & $1.41^{\mathrm{A}}$ & A24 & $1.06^{\mathrm{A}}$ & \\
\hline & A4 & $1.16^{\mathrm{B}}$ & A25 & $1.52^{C}$ & \\
\hline & A6 & $1.36^{\mathrm{A}}$ & A27 & $1.28^{\mathrm{B}}$ & \\
\hline & A10 & $1.67^{\mathrm{A}}$ & A28 & $3.52^{\mathrm{B}}$ & \\
\hline & A18 & $1.89^{\mathrm{A}}$ & A29 & $1.08^{\mathrm{B}}$ & \\
\hline & A19 & $1.57^{\mathrm{A}}$ & A30 & $1.24^{\mathrm{B}}$ & \\
\hline & A20 & $1.09^{\mathrm{A}}$ & A47 & $3.28^{\mathrm{A}}$ & \\
\hline \multirow{7}{*}{ 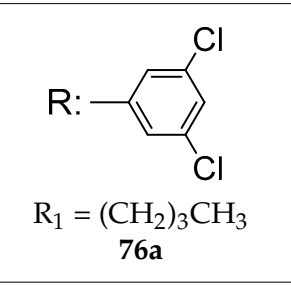 } & A1 & $1.51^{\mathrm{C}}$ & A21 & $1.68^{\mathrm{A}}$ & \\
\hline & A2 & $1.61^{\mathrm{B}}$ & A24 & $1.34^{\mathrm{A}}$ & \\
\hline & A4 & $1.09^{C}$ & A25 & $1.10^{\mathrm{A}}$ & \\
\hline & A6 & $1.50^{\mathrm{B}}$ & A27 & $1.40^{\mathrm{B}}$ & \\
\hline & A10 & $1.07^{\mathrm{B}}$ & A28 & $4.10^{C}$ & \\
\hline & A18 & $1.26^{\mathrm{A}}$ & A30 & $1.17^{\mathrm{A}}$ & \\
\hline & A19 & $1.54^{\mathrm{A}}$ & A47 & $1.87^{\mathrm{A}}$ & \\
\hline \multirow{9}{*}{$\mathrm{R}_{1}=\underset{\substack{\left(\mathrm{CH}_{2}\right)_{3} \mathrm{CH}_{3} \\
\mathbf{7 6 b}}}{\mathrm{R}:{ }^{-}}$} & A1 & $1.49^{C}$ & A24 & $1.53^{\mathrm{A}}$ & \\
\hline & A2 & $1.47^{\mathrm{A}}$ & A25 & $3.55^{C}$ & \\
\hline & A4 & $1.21^{\mathrm{C}}$ & A27 & $1.68^{\mathrm{A}}$ & \\
\hline & A6 & $1.23^{\mathrm{B}}$ & A28 & $1.99^{\mathrm{A}}$ & \\
\hline & A10 & $1.07^{C}$ & A29 & $1.30^{\mathrm{A}}$ & \\
\hline & A18 & $1.96^{\mathrm{B}}$ & A30 & $6.71^{C}$ & \\
\hline & A19 & $2.23^{C}$ & A47 & $1.30^{\mathrm{A}}$ & \\
\hline & A20 & $1.31^{\mathrm{A}}$ & A55 & $1.10^{\mathrm{A}}$ & \\
\hline & A21 & $1.10^{\mathrm{A}}$ & & & \\
\hline
\end{tabular}


In the same year, some bis-phenylcarbamate derivatives with different substituents in both phenylcarbamate and amine moieties (58-61) were obtained by the same group (Table 5) [69]. The synthesized chitosan derivatives were coated on aminopropyl silica, and showed chiral recognition for the majority of the tested racemates. These new CSPs also proved to be stable when used with other mobile phases than the typical hexane/2-propanol [69].

Other CSPs based on the substitution of the amine of chitosan with an alkyl moiety, prior to the derivatization of the hydroxyl groups with different isocyanates were described $[68,70]$. Actually, Feng et al., prepared several bis-4-methylphenylcarbamates with different alkyl moieties linked in the amine group of chitosan (62-64) (Table 5) [68]. These derivatives were coated on aminopropyl silica and showed good chiral recognition abilities, being equivalent to the CSP comprising 3,5-dimethylphenylcarbamate of amylose.

Furthermore, Zhang et al., developed several CSPs based on N-cyclobutylformilated chitosan derivatives (65-71) (Table 5) [70]. These CSPs showed good chiral recognition abilities, specially the CSPs comprising the chitosan-derivatives 66,67 and 68 , being able to recognize most of the tested racemates. Additional analysis were performed to evaluate the tolerability to other organic solvents, which showed no significant changes in the enantiorecognition abilities of the tested CSPs after being flushed with ethyl acetate $(100 \%)$, chloroform $(100 \%)$ and hexane/tetrahydrofuran $(50 / 50,40 / 60$, $30 / 70 v / v)[70]$.

Recently, Feng et al., developed several new CSPs containing a n-pentyl-amide moiety (72-76b) (Table 5) [71]. The LC performance of these CSPs was evaluated, and proved to have high chiral recognition abilities. The influence of the molecular weight of the chitosan on the chiral recognition capability of the developed CSPs (76a and $\mathbf{7 6 b}$ ) was also evaluated, showing that a lower molecular weight allowed better chiral recognition abilities, resolving $N$-(1-phenylethyl)benzamide $(\alpha=1.30)$ and 3-(dimethylamino)-1-thiophen-2-yl)propan-1-ol $(\alpha=1.10)$ whilst CSP $76 \mathbf{b}$ was not able to resolve these racemates. Once again, this type of CSPs (chitosan-based) showed high tolerability for other organic solvents than the typically used for coated-type CSPs.

Wang et al., developed several new chitosan bis-phenylcarbamates with the amine moiety being derivatized with a N-octyl urea (77-82) (Table 6) [72]. The obtained CSPs showed good chiral recognition abilities, being equivalent to those comprising 3,5-dimethylphenylcarbamates of amylose and cellulose. For instance, these CSPs were capable of resolving several racemates such as voriconazole with $\alpha$ values higher than 1.95 .

Other chitosan bis-3,5-dimethylphenylcarbamates with different moieties linked to the chitosan amine group (83-87) were developed by Wang et al., (Table 6) [73]. The obtained CSPs showed good chiral recognition abilities, especially the CSP comprising the chitosan-derivative 87 , which was able to recognize all the tested racemates, such as Troger's base $(\alpha=1.33)$, benzoin $(\alpha=1.47)$ and voriconazole $(\alpha=2.89)$.

To our knowledge, the most recent study on chitosan bis-phenylcarbamate derivatives was published by Liang et al., [74]. In this study, several CSPs based on chitosan $N$-isobutylurea (88a-91b) were prepared (Table 6). Two types of chitosan with different molecular weights were used. In this study, the CSPs developed with higher molecular weight chitosan (88a, 89a, 91a) showed lower chiral recognition ability than their low molecular weight chitosan counterparts $(\mathbf{8 8 b}, \mathbf{8 9 b}, \mathbf{9 1 b})$, with the exception of derivative 90a that showed higher chiral recognition ability than derivative $\mathbf{9 0 b}$. These CSPs were also able to withstand organic solvents such as ethyl acetate $(100 \%)$ and chloroform $(100 \%)[74]$. 
Table 6. Chitosan bis-carbamate CSPs with the amine moiety of chitosan modified by an N-alkyl urea.

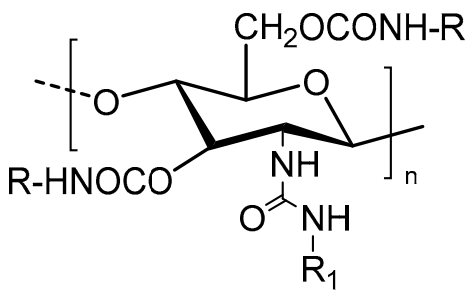

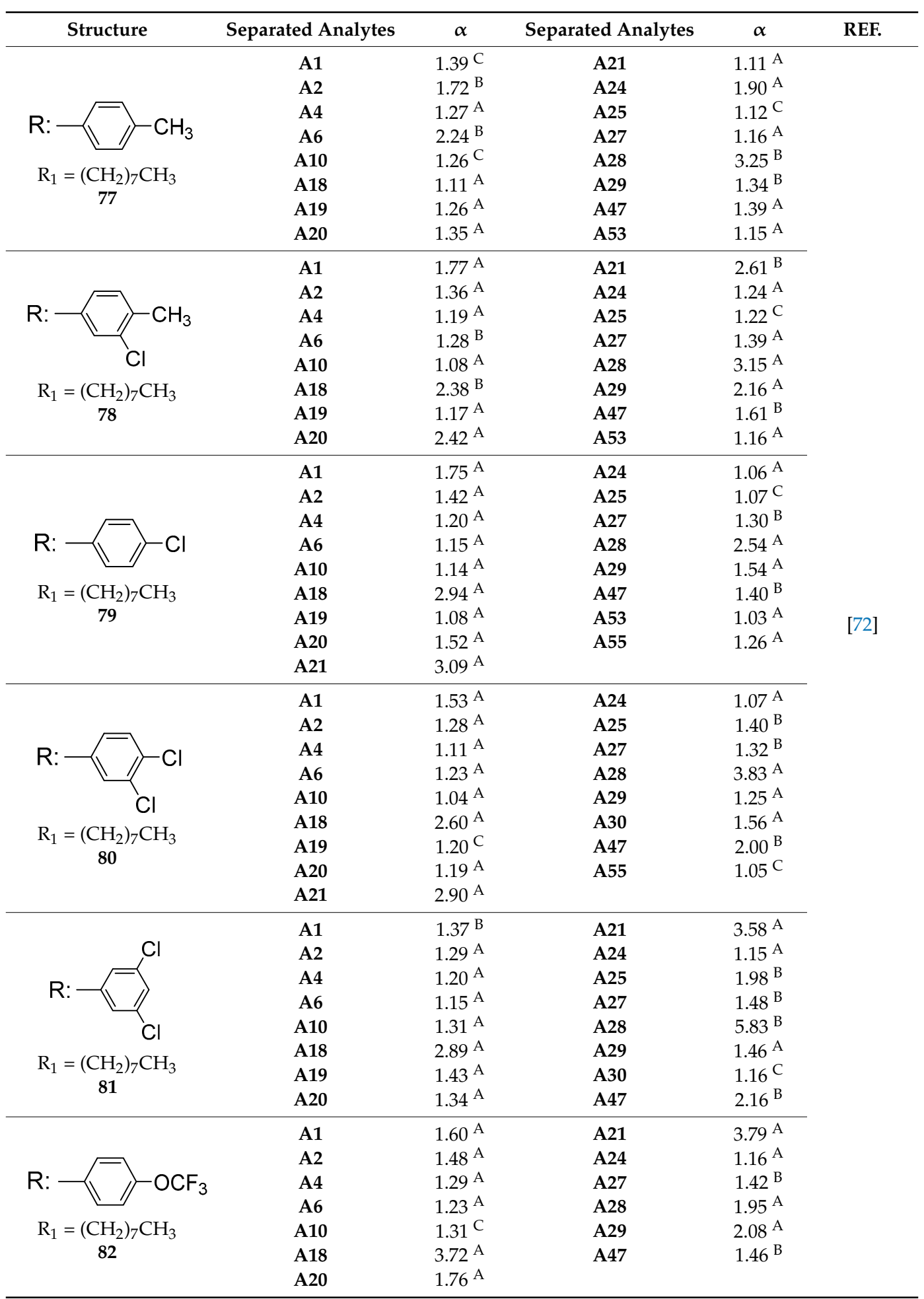


Table 6. Cont.

\begin{tabular}{|c|c|c|c|c|c|}
\hline Structure & Separated Analytes & $\alpha$ & Separated Analytes & $\alpha$ & REF. \\
\hline \multirow{8}{*}{$\mathrm{R}_{1}=\underset{\mathbf{8 3}}{\left(\mathrm{CH}_{2}\right)_{7} \mathrm{CH}_{3}}$} & A1 & $2.42^{\mathrm{B}}$ & A21 & $1.97^{\mathrm{A}}$ & \multirow{41}{*}{ [73] } \\
\hline & A2 & $1.48^{\mathrm{A}}$ & A23 & $1.30^{\mathrm{C}}$ & \\
\hline & $\mathrm{A} 4$ & $1.12^{\mathrm{B}}$ & A24 & $1.30^{\mathrm{A}}$ & \\
\hline & A6 & $1.75^{\mathrm{B}}$ & A25 & $1.10^{\mathrm{A}}$ & \\
\hline & A10 & $1.19^{\mathrm{B}}$ & A26 & $1.17^{\mathrm{C}}$ & \\
\hline & A18 & $1.73^{\mathrm{A}}$ & A27 & $1.35^{\mathrm{A}}$ & \\
\hline & A19 & $1.32^{\mathrm{A}}$ & A28 & $6.98^{\mathrm{B}}$ & \\
\hline & A20 & $1.05^{\mathrm{A}}$ & A36 & $1.20^{\mathrm{B}}$ & \\
\hline \multirow{8}{*}{$\mathrm{R}:=\underset{\mathbf{8 4}}{\mathrm{R}_{1}=\mathrm{CH}_{2} \mathrm{C}_{6} \mathrm{H}_{5}}$} & A1 & $1.38^{\mathrm{B}}$ & A21 & $1.44^{\mathrm{A}}$ & \\
\hline & A2 & $1.50^{\mathrm{A}}$ & A23 & $1.08^{\mathrm{B}}$ & \\
\hline & A4 & $1.04^{\mathrm{B}}$ & A24 & $1.31^{\mathrm{A}}$ & \\
\hline & A6 & $9.61^{\mathrm{B}}$ & A25 & $1.18^{\mathrm{A}}$ & \\
\hline & A10 & $1.13^{\mathrm{B}}$ & A26 & $1.28^{\mathrm{C}}$ & \\
\hline & A18 & $1.17^{\mathrm{A}}$ & A27 & $1.28^{\mathrm{A}}$ & \\
\hline & A19 & $1.18^{\mathrm{B}}$ & A28 & $3.30^{\mathrm{A}}$ & \\
\hline & A20 & $1.18^{\mathrm{A}}$ & A36 & $1.19^{\mathrm{A}}$ & \\
\hline \multirow{8}{*}{$\mathrm{R}: \mathrm{R}_{1}=\underset{85}{\left(\mathrm{CH}_{2}\right)_{3} \mathrm{CH}_{3}}$} & A1 & $1.26^{\mathrm{C}}$ & A21 & $1.16^{\mathrm{A}}$ & \\
\hline & A2 & $1.12^{\mathrm{B}}$ & A23 & $1.34^{\mathrm{B}}$ & \\
\hline & A4 & $1.48^{\mathrm{A}}$ & A24 & $1.09^{\mathrm{B}}$ & \\
\hline & A6 & $1.06^{\mathrm{B}}$ & A25 & $1.30^{\mathrm{A}}$ & \\
\hline & A10 & $1.05^{\mathrm{A}}$ & A26 & $4.27^{\mathrm{A}}$ & \\
\hline & A18 & $1.48^{\mathrm{A}}$ & $\mathrm{A} 27$ & $1.71^{\mathrm{B}}$ & \\
\hline & A19 & $1.21^{\mathrm{A}}$ & A28 & $1.40^{\mathrm{A}}$ & \\
\hline & A20 & $1.19^{\mathrm{A}}$ & A36 & $1.19^{\mathrm{B}}$ & \\
\hline \multirow{8}{*}{$\mathrm{R}: \mathrm{R}_{\mathbf{8 6}} \mathrm{CH}_{\mathbf{8 6}}^{\left(\mathrm{CH}_{2}\right)_{11} \mathrm{CH}_{3}}$} & A1 & $1.32^{B}$ & A23 & $1.19^{\mathrm{A}}$ & \\
\hline & A2 & $1.41 \mathrm{~A}$ & A24 & $1.34^{\mathrm{A}}$ & \\
\hline & A5 & $1.05^{C}$ & A25 & $1.21^{\mathrm{A}}$ & \\
\hline & A6 & $1.54^{\mathrm{B}}$ & A26 & $1.28^{\mathrm{C}}$ & \\
\hline & A10 & $1.14^{\mathrm{B}}$ & A27 & $1.30^{\mathrm{A}}$ & \\
\hline & A18 & $1.52^{\mathrm{A}}$ & A28 & $3.38^{\mathrm{A}}$ & \\
\hline & A19 & $1.16^{\mathrm{B}}$ & A36 & $1.26^{\mathrm{A}}$ & \\
\hline & A21 & $1.93^{\mathrm{A}}$ & & & \\
\hline \multirow{9}{*}{$\begin{array}{c}\mathrm{R}: \\
\mathrm{R}_{1}=\mathrm{C}_{6} \mathrm{H}_{11} \\
\mathbf{8 7}\end{array}$} & A1 & $1.33^{\mathrm{A}}$ & A21 & $1.28^{\mathrm{A}}$ & \\
\hline & A2 & $1.47^{\mathrm{A}}$ & A23 & $1.22^{\mathrm{A}}$ & \\
\hline & A4 & $1.05^{\mathrm{A}}$ & A24 & $1.16^{\mathrm{B}}$ & \\
\hline & A5 & $1.05^{\mathrm{B}}$ & A25 & $1.32^{\mathrm{A}}$ & \\
\hline & A6 & $1.47^{\mathrm{B}}$ & A26 & $1.11^{\mathrm{C}}$ & \\
\hline & A10 & $1.22^{\mathrm{A}}$ & A27 & $1.17^{\mathrm{A}}$ & \\
\hline & A18 & $1.25^{\mathrm{B}}$ & A28 & $2.89^{\mathrm{B}}$ & \\
\hline & A19 & $1.22^{\mathrm{B}}$ & A36 & $1.15^{\mathrm{A}}$ & \\
\hline & A20 & $1.12^{\mathrm{A}}$ & A54 & $1.11^{\mathrm{A}}$ & \\
\hline \multirow{8}{*}{$\mathrm{R}: \mathrm{R}_{1}=\mathrm{CH}_{\mathbf{8 8}} \mathrm{CH}\left(\mathrm{CH}_{3}\right)_{2}$} & A1 & $2.47^{\mathrm{B}}$ & A24 & $1.22^{\mathrm{A}}$ & \multirow{17}{*}{ [74] } \\
\hline & A2 & $1.49^{\mathrm{B}}$ & A25 & $1.15^{\mathrm{A}}$ & \\
\hline & A4 & $1.08^{\mathrm{B}}$ & A27 & $1.36^{\mathrm{A}}$ & \\
\hline & A6 & $1.34^{\mathrm{B}}$ & A28 & $3.30^{\mathrm{A}}$ & \\
\hline & A10 & $1.06^{\mathrm{B}}$ & A30 & $1.19^{\mathrm{B}}$ & \\
\hline & A18 & $1.53^{\mathrm{B}}$ & A47 & $1.50^{\mathrm{B}}$ & \\
\hline & A19 & $1.17^{\mathrm{A}}$ & A53 & $1.06^{\mathrm{A}}$ & \\
\hline & A21 & $1.76^{\mathrm{A}}$ & & & \\
\hline \multirow{9}{*}{$\begin{array}{c}\mathrm{CH}_{3} \\
\mathrm{R}_{1}=\underset{\mathbf{8 8 b}}{\mathrm{CH}_{2} \mathrm{CH}\left(\mathrm{CH}_{3}\right)_{2}}\end{array}$} & A1 & $1.21^{\mathrm{B}}$ & A24 & $1.99 \mathrm{~A}$ & \\
\hline & A2 & $1.63^{\mathrm{A}}$ & A25 & $1.33^{C}$ & \\
\hline & A4 & $1.09^{\mathrm{B}}$ & A27 & $1.29^{\mathrm{A}}$ & \\
\hline & A6 & $1.37^{\mathrm{C}}$ & A28 & $7.45^{\mathrm{B}}$ & \\
\hline & A10 & $1.12^{\mathrm{A}}$ & A29 & $1.30^{\mathrm{A}}$ & \\
\hline & A18 & $1.10^{\mathrm{B}}$ & A47 & $1.37^{\mathrm{B}}$ & \\
\hline & A19 & $1.28^{\mathrm{A}}$ & A53 & $1.22^{\mathrm{A}}$ & \\
\hline & A20 & $1.16^{\mathrm{A}}$ & A54 & $1.09 \mathrm{~A}$ & \\
\hline & A21 & $1.37^{\mathrm{A}}$ & A55 & $1.15^{\mathrm{A}}$ & \\
\hline
\end{tabular}


Table 6. Cont.

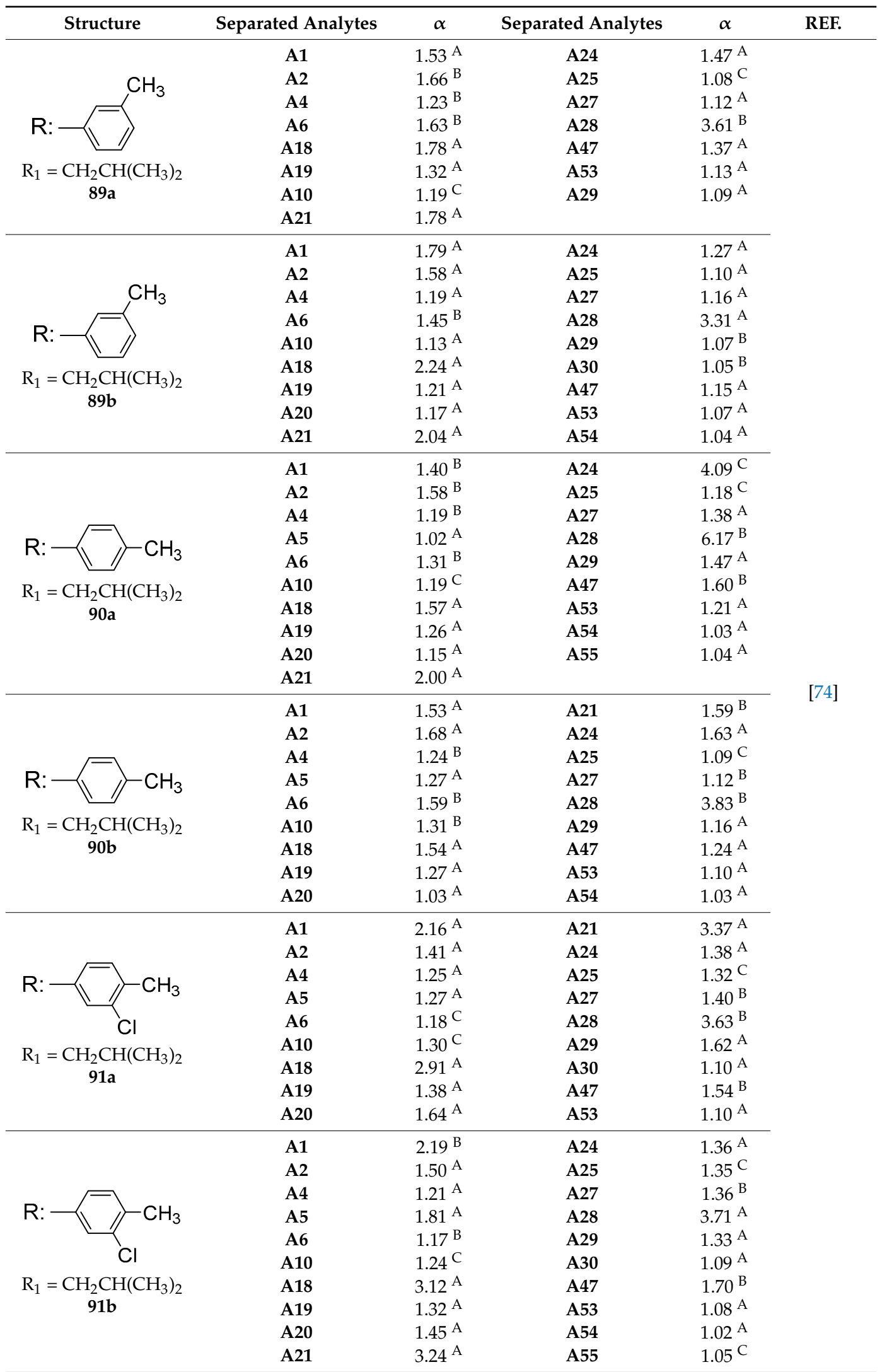

A_- Hex/2-PrOH (90:10 v/v); ${ }^{\mathrm{B}}-\mathrm{Hex} / \mathrm{EtOH}(90: 10 v / v) ;{ }^{\mathrm{C}}-\mathrm{Hex} / 2-\mathrm{EtOH} / \mathrm{MeOH}(90: 5: 5 v / v / v), 1.0 \mathrm{~mL} / \mathrm{min}$. Coated with DMF on APS. APS-Aminopropyl silica; DMF-Dimethylformamide; Hex- $n$-Hexane; 2-PrOH-2-Propanol; $\mathrm{EtOH}$-Ethanol; $\mathrm{MeOH}-$ Methanol; a-CSPs developed with higher Molecular weight chitosan; $\mathrm{b}$-CSPs developed with lower Molecular weight chitosan. 


\subsubsection{Chitosan Amine-Carbamate CSPs}

Liu et al., in 2006, postulated that the development of a chitosan CSP would be an excellent tool to be used in chiral ligand-exchange chromatography (CLEC), considering the high binding capacity of chitosan to heavy metals [75]. Consequently, they described the immobilization of chitosan into silica gel and the application of the obtained CSP (Figure 5) in CLEC to achieve enantioresolution of a variety of $\alpha$-hydroxycarboxylic acids and $\alpha$-aminoacids using $\mathrm{CuSO}_{4} 100 \%$ or $\mathrm{CuSO}_{4} / \mathrm{MeOH}$ $(80: 20 \mathrm{v} / \mathrm{v})$ as mobile phases [75]. To the best of our knowledge, this is the only report related to the application of chitosan-derived CSPs for this type of study.

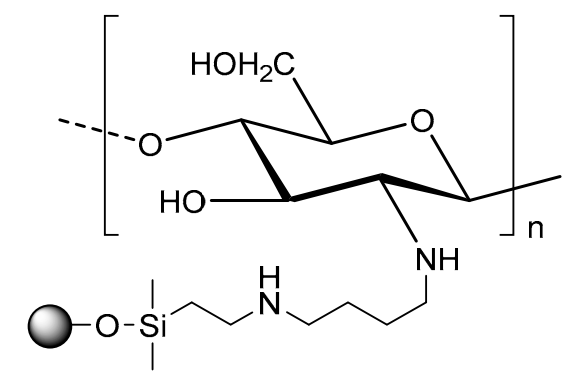

Figure 5. Structure of chitosan amine-derived CSP.

\section{Conclusions}

Polysaccharide-based CSPs are of great value and are being recognized as highly successful for both analytical and preparative separations. Among them, amylose and cellulose carbamate derivatives are the most widely used CSPs for the efficient resolution of several racemates revealing very high chiral recognition abilities.

Although several efficient polysaccharide-based CSPs are described in the literature and many of them are commercially available, studies on new and improved polysaccharide-based CSPs are still being conducted. The research is mainly focused on the immobilization of the chiral selectors on chromatographic support, allowing the use of a wider range of mobile phases and, consequently, increasing the range of their applications. Polysaccharide-based CSPs comprising other natural polymers and derivatives such as tris-phenylcarbamates of chitin and chitosan as well as bis-phenylcarbamates of chitosan also showed high chiral recognition abilities being able to resolve diverse types of racemates. Most of these CSPs were obtained by the traditional coating method; however, regarding their poor solubility they were able to perform enantioseparations under reversed phase as well as using different solvents as components of the mobile phases in normal phase, such as chloroform and ethyl acetate. Some chitosan-based CSPs were also prepared by immobilization of the chiral selector on the chromatographic support.

Acknowledgments: This work was partially supported through national funds provided by FCT/ MCTES-Foundation for Science and Technology from the Minister of Science, Technology and Higher Education (PIDDAC) and European Regional Development Fund (ERDF) through the COMPETE-Programa Operacional Factores de Competitividade (POFC) programme, under the Strategic Funding UID/Multi/04423/2013, the project PTDC /MAR-BIO/4694/2014 (reference POCI-01-0145-FEDER-016790; Project 3599-Promover a Produção Científica e Desenvolvimento Tecnológico e a Constituição de Redes Temáticas (3599-PPCDT)) in the framework of the programme PT2020 as well as by the project INNOVMAR-Innovation and Sustainability in the Management and Exploitation of Marine Resources (reference NORTE-01-0145-FEDER-000035, within Research Line NOVELMAR), supported by North Portugal Regional Operational Programme (NORTE 2020), under the PORTUGAL 2020 Partnership Agreement, through the European Regional Development Fund (ERDF), and Chiral_Drugs_CESPU_2017.

Author Contributions: João Ribeiro with the supervision of Carla Fernandes analyzed the references, evaluated the information relevant to the topic and wrote the paper Maria Elizabeth Tiritan helped in bibliographic research, evaluated the information relevant to the topic and reviewed the final version of the manuscript. 
Madalena M. M. Pinto contributed with discussion during the preparation of the manuscript and reviewed the final version of the manuscript.

Conflicts of Interest: The authors declare no conflict of interest.

\section{References}

1. Cavazzini, A.; Pasti, L.; Massi, A.; Marchetti, N.; Dondi, F. Recent applications in chiral high performance liquid chromatography: A review. Anal. Chim. Acta 2011, 706, 205-222. [CrossRef] [PubMed]

2. Fernandes, C.; Phyo, Y.; Silva, A.S.; Tiritan, M.E.; Kijjoa, A.; Pinto, M.M.M. Chiral stationary phases based on small molecules: An update of the last seventeen years. Sep. Purif. Rev. 2017. [CrossRef]

3. Fernandes, C.; Tiritan, M.E.; Pinto, M. Small molecules as chromatographic tools for HPLC enantiomeric resolution: Pirkle-type chiral stationary phases evolution. Chromatographia 2013, 76, 871-897. [CrossRef]

4. Lämmerhofer, M. Chiral recognition by enantioselective liquid chromatography: Mechanisms and modern chiral stationary phases. J. Chromatogr. A 2010, 1217, 814-856. [CrossRef] [PubMed]

5. Morrison, R.T.; Boyd, R.N. Organic Chemistry, 6th ed.; Prentice-Hall International: London, UK, 1992.

6. Hesse, G.; Hagel, R. A complete separation of a racemic mixture by elution chromatography on cellulose triacetate. Chromatographia 1973, 6, 277-280. [CrossRef]

7. Okamoto, Y.; Kawashima, M.; Hatada, K. Useful chiral packing materials for high-performance liquid chromatographic resolution of enantiomers: Phenylcarbamates of polysaccharides coated on silica gel. J. Am. Chem. Soc. 1984, 106, 5357-5359. [CrossRef]

8. Witte, D.T.; Bruggeman, F.J.; Franke, J.P.; Copinga, S.; Jansen, J.M.; De Zeeuw, R.A. Comparison between cellulose and amylose tris(3,5-dimethylphenylcarbamate) chiral stationary phases for enantiomeric separation of 17 amidotetralins. Chirality 1993, 5, 545-553. [CrossRef]

9. Matlin, S.A.; Tiritan, M.E.; Crawford, A.J.; Cass, Q.B.; Boyd, D.R. HPLC with carbohydrate carbamate chiral phases: Influence of chiral phase structure on enantioselectivity. Chirality 1994, 6, 135-140. [CrossRef]

10. Chankvetadze, B.; Yashima, E.; Okamoto, Y. Dimethyl-, dichloro- and chloromethylphenylcarbamates of amylose as chiral stationary phases for high-performance liquid chromatography. J. Chromatogr. A 1995, 694, 101-109. [CrossRef]

11. Park, J.H.; Whang, Y.C.; Jung, Y.J.; Okamoto, Y.; Yamamoto, C.; Carr, P.W.; McNeff, C.V. Separation of racemic compounds on amylose and cellulose dimethylphenylcarbamate-coated zirconia in HPLC. J. Sep. Sci. 2003, 26, 1331-1336. [CrossRef]

12. Shen, J.; Zhao, Y.; Inagaki, S.; Yamamoto, C.; Shen, Y.; Liu, S.; Okamoto, Y. Enantioseparation using orthoor meta-substituted phenylcarbamates of amylose as chiral stationary phases for high-performance liquid chromatography. J. Chromatogr. A 2013, 1286, 41-46. [CrossRef] [PubMed]

13. Chankvetadze, B.; Yashima, E.; Okamoto, Y. Chloromethylphenylcarbamate derivatives of cellulose as chiral stationary phases for high-performance liquid chromatography. J. Chromatogr. A 1994, 670, 39-49. [CrossRef]

14. Kaida, Y.; Okamoto, Y. Optical resolution by high-performance liquid chromatography on benzylcarbamates of cellulose and amylose. J. Chromatogr. A 1993, 641, 267-278. [CrossRef]

15. Cass, Q.B.; Tiritan, M.E.; Calafatti, S.A.; Matlin, S.A. Enantioseparation on amylose triso,5-dimethoxyphenyl carbamate): Application to commercial pharmaceutical chiral drugs. J. Liq. Chromatogr. Relat. Technol. 1999, 22, 3091-3099. [CrossRef]

16. Ichida, A.; Shibata, T.; Okamoto, I.; Yuki, Y.; Namikoshi, H.; Toga, Y. Resolution of enantiomers by HPLC on cellulose derivatives. Chromatographia 1984, 19, 280-284. [CrossRef]

17. Castells, C.B.; Carr, P.W. Cellulose tris(3,5-dimethylphenylcarbamate)-coated zirconia as a chiral stationary phase for HPLC. Anal. Chem. 1999, 71, 3013-3021. [CrossRef] [PubMed]

18. Castells, C.B.; Carr, P.W. Fast enantioseparations of basic analytes by high-performance liquid chromatography using cellulose tris(3,5-dimethylphenylcarbamate)-coated zirconia stationary phases. J. Chromatogr. A 2000, 904, 17-33. [CrossRef]

19. Kasuya, N.; Kusaka, Y.; Habu, N.; Ohnishi, A. Development of chiral stationary phases consisting of low-molecular-weight cellulose derivatives covalently bonded to silica gel. Cellulose 2002, 9, 263-269. [CrossRef]

20. Chen, X.; Zou, H.; Ni, J.; Feng, S. Synthesis and characteristics of composite chiral stationary phases based on cellulose derivatives. J. Sep. Sci. 2003, 26, 29-36. [CrossRef] 
21. Liu, Y.; Zou, H. High-performance liquid chromatographic evaluation of a coated cellulose tris(3,5-dimethylphenylcarbamate) chiral stationary phase having a small-pore silica support. J. Chromatogr. A 2008, 1178, 118-125. [CrossRef] [PubMed]

22. Cass, Q.B.; Bassi, A.L.; Calafatti, S.A.; Matlin, S.A.; Tiritan, M.E.; de Campos, L.M.M. Carbohydrate carbamate coated onto microporous silica: Application to chiral analysis of commercial pharmaceutical drugs. Chirality 1996, 8, 143-146. [CrossRef]

23. Matlin, S.A.; Tiritan, M.E.; Cass, Q.B.; Boyd, D.R. Enantiomeric resolution of chiral sulfoxides on polysaccharide phases by HPLC. Chirality 1996, 8, 147-152. [CrossRef]

24. Yashima, E. Polysaccharide-based chiral stationary phases for high-performance liquid chromatographic enantioseparation. J. Chromatogr. A 2001, 906, 105-125. [CrossRef]

25. Ali, I.; Aboul-Enein, H.Y. Immobilized polysaccharide CSPs: An advancement in enantiomeric separations. Curr. Pharm. Anal. 2007, 3, 71-82. [CrossRef]

26. Ikai, T.; Okamoto, Y. Structure control of polysaccharide derivatives for efficient separation of enantiomers by chromatography. Chem. Rev. 2009, 109, 6077-6101. [CrossRef] [PubMed]

27. Al-Othman, Z.A.; Ali, I.; Asim, M.; Khan, T.A. Recent trends in chiral separations on immobilized polysaccharides CSPs. Comb. Chem. High Throughput Screen. 2012, 15, 339-346. [CrossRef] [PubMed]

28. Chankvetadze, B. Recent developments on polysaccharide-based chiral stationary phases for liquid-phase separation of enantiomers. J. Chromatogr. A 2012, 1269, 26-51. [CrossRef] [PubMed]

29. Chen, X.; Yamamoto, C.; Okamoto, Y. Polysaccharide derivatives as useful chiral stationary phases in high-performance liquid chromatography. Pure Appl. Chem. 2007, 79, 1561-1573. [CrossRef]

30. Ali, I.; Saleem, K.; Hussain, I.; Gaitonde, V.D.; Aboul-Enein, H.Y. Polysaccharides chiral stationary phases in liquid chromatography. Sep. Purif. Rev. 2009, 38, 97-147. [CrossRef]

31. Maier, N.M.; Franco, P.; Lindner, W. Separation of enantiomers: needs, challenges, perspectives. J. Chromatogr. A 2001, 906, 3-33. [CrossRef]

32. Ikai, T.; Yamamoto, C.; Kamigaito, M.; Okamoto, Y. Immobilized-type chiral packing materials for HPLC based on polysaccharide derivatives. J. Chromatogr. B Anal. Technol. Biomed. Life Sci. 2008, 875, 2-11. [CrossRef] [PubMed]

33. Okamoto, Y.; Ikai, T. Chiral HPLC for efficient resolution of enantiomers. Chem. Soc. Rev. 2008, 37, $2593-2608$. [CrossRef] [PubMed]

34. Shen, J.; Okamoto, Y. Efficient separation of enantiomers using stereoregular chiral polymers. Chem. Rev. 2016, 116, 1094-1138. [CrossRef] [PubMed]

35. Fanali, C.; Fanali, S.; Chankvetadze, B. HPLC separation of enantiomers of some flavanone derivatives using polysaccharide-based chiral selectors covalently immobilized on silica. Chromatographia 2016, 79, 119-124. [CrossRef]

36. Belboukhari, N.; Lahmar, N.; Sekkoum, K.; Cheriti, A.; Aboul-Enein, H.Y. Chiral separation of several flavanones by liquid chromatography. Curr. Pharm. Anal. 2015, 11, 201-209. [CrossRef]

37. López-Ram-de-Víu, P.; Gálvez, J.A.; Díaz-de-Villegas, M.D. High-performance liquid chromatographic enantioseparation of unusual amino acid derivatives with axial chirality on polysaccharide-based chiral stationary phases. J. Chromatogr. A 2015, 1390, 78-85. [CrossRef] [PubMed]

38. Albals, D.; Heyden, Y.V.; Schmid, M.G.; Chankvetadze, B.; Mangelings, D. Chiral separations of cathinone and amphetamine-derivatives: Comparative study between capillary electrochromatography, supercritical fluid chromatography and three liquid chromatographic modes. J. Pharm. Biomed. Anal. 2016, 121, 232-243. [CrossRef] [PubMed]

39. Ghanem, A.; Hoenen, H.; Müller, P.; Aboul-Enein, H.Y. Enantiomeric separation of cyclopropane derivatives on a polysaccharide-based chiral stationary phase. Anal. Chim. Acta 2005, 538, 15-24. [CrossRef]

40. Lipka, E.; Yous, S.; Furman, C.; Carato, P.; Deghaye, C.; Bonte, J.P.; Vaccher, C. Analytical and preparative chiral separation of $\beta$-carboline derivatives, LDL oxidation inhibitors, using HPLC and CE methodologies: Determination of enantiomeric purity. Chromatographia 2012, 75, 337-345. [CrossRef]

41. Gallinella, B.; Ferretti, R.; Zanitti, L.; Sestili, I.; Mosca, A.; Cirilli, R. Comparison of reversed-phase enantioselective HPLC methods for determining the enantiomeric purity of (S)-omeprazole in the presence of its related substances. J. Pharm. Anal. 2016, 6, 132-136. [CrossRef] 
42. Okamoto, Y.; Kawashima, M.; Hatada, K. Chromatographic resolution: XI. Controlled chiral recognition of cellulose triphenylcarbamate derivatives supported on silica gel. J. Chromatogr. A 1986, 363, 173-186. [CrossRef]

43. Okamoto, Y.; Aburatani, R.; Miura, S.I.; Hatada, K. Chiral stationary phases for HPLC: Cellulose tris(3,5-dimethylphenyl-carbamate) and tris(3,5-dichlorophenylcarbamate) chemically bonded to silica gel. J. Liq. Chromatogr. 1987, 10, 1613-1628. [CrossRef]

44. Franco, P.; Senso, A.; Minguillón, C.; Oliveros, L. 3,5-dimethylphenylcarbamates of amylose, chitosan and cellulose bonded on silica gel comparison of their chiral recognition abilities as high-performance liquid chromatography chiral stationary phases. J. Chromatogr. A 1998, 796, 265-272. [CrossRef]

45. Francotte, E.; Huynh, D. Immobilized halogenophenylcarbamate derivatives of cellulose as novel stationary phases for enantioselective drug analysis. J. Pharm. Biomed. Anal. 2002, 27, 421-429. [CrossRef]

46. Jeuniaux, C. A brief survey of the early contribution of European scientists to chitin knowledge. In Advances in Chitin Sciences; Domard, A.J.C., Muzzarelli, R.A.A., Roberts, G., Eds.; Jacques André Publishers: Lyon, France, 1996; pp. 1-9.

47. Khor, E. Chapter 1-The relevance of chitin. In Chitin; Elsevier Science Ltd.: Amsterdam, The Netherlands, 2001; pp. 1-8.

48. Rinaudo, M. Chitin and chitosan: Properties and applications. Prog. Polym. Sci. 2006, 31, 603-632. [CrossRef]

49. Hou, J.; Yu, X.; Shen, Y.; Shi, Y.; Su, C.; Zhao, L. Triphenyl phosphine-functionalized chitosan nanoparticles enhanced antitumor efficiency through targeted delivery of doxorubicin to mitochondria. Nanoscale Res. Lett. 2017, 12, 158. [CrossRef] [PubMed]

50. Kato, Y.; Onishi, H.; Machida, Y. Application of chitin and chitosan derivatives in the pharmaceutical field. Curr. Pharm. Biotechnol. 2003, 4, 303-309. [CrossRef] [PubMed]

51. Venkatesan, J.; Vinodhini, P.A.; Sudha, P.N.; Kim, S.K. Chitin and chitosan composites for bone tissue regeneration. Adv. Food Nutr. Res. 2014, 73, 59-81. [PubMed]

52. Krajewska, B. Application of chitin- and chitosan-based materials for enzyme immobilizations: A review. Enzyme Microb. Technol. 2004, 35, 126-139. [CrossRef]

53. Cass, Q.B.; Bassi, A.L.; Matlin, S.A. Chiral discrimination by HPLC on aryl carbamate derivatives of chitin coated onto microporous aminopropyl silica. Chirality 1996, 8, 131-135. [CrossRef]

54. Yamamoto, C.; Hayashi, T.; Okamoto, Y. High-performance liquid chromatographic enantioseparation using chitin carbamate derivatives as chiral stationary phases. J. Chromatogr. A 2003, 1021, 83-91. [CrossRef] [PubMed]

55. Yamamoto, C.; Hayashi, T.; Okamoto, Y.; Kobayashi, S. Enantioseparation by using chitin phenylcarbamates as chiral stationary phases for high-performance liquid chromatography. Chem. Lett. 2000, 29, 12-13. [CrossRef]

56. Zhang, J.; Wang, Z.Q.; Wang, X.C.; Zhang, J.J.; Bai, Z.W.; Chen, W. Enantioseparation characteristics of tadalafil and its intermediate on chitin derived chiral stationary phases. Analyst 2015, 140, 5593-5600. [CrossRef] [PubMed]

57. Wang, X.C.; Zhang, J.; Xu, X.Q.; Chen, W.; Yang, Y.G.; Bai, Z.W. Enantioseparation characteristics of chiral stationary phases based on the derivatives of cellulose and chitin. Anal. Methods 2015, 7, 2786-2793. [CrossRef]

58. Zhang, J.; Wang, Z.Q.; Chen, W.; Bai, Z.W. Preparation and enantioseparation of biselector chiral stationary phases based on amylose and chitin derivatives. Anal. Sci. 2015, 31, 1091-1097. [CrossRef] [PubMed]

59. Zhang, L.; Shen, J.; Zuo, W.; Okamoto, Y. Synthesis of chitosan 3,6-diphenylcarbamate-2-urea derivatives and their applications as chiral stationary phases for high-performance liquid chromatography. J. Chromatogr. A 2014, 1365, 86-93. [CrossRef] [PubMed]

60. Okamoto, Y.; Noguchi, J.; Yashima, E. Enantioseparation on 3,5-dichloro- and 3,5-dimethylphenylcarbamates of polysaccharides as chiral stationary phases for high-performance liquid chromatography. Reac. Func. Polym. 1998, 37, 183-188. [CrossRef]

61. Senso, A.; Oliveros, L.; Minguillón, C. Chitosan derivatives as chiral selectors bonded on allyl silica gel: Preparation, characterisation and study of the resulting high-performance liquid chromatography chiral stationary phases. J. Chromatogr. A 1999, 839, 15-21. [CrossRef] 
62. Yamamoto, C.; Fujisawa, M.; Kamigaito, M.; Okamoto, Y. Enantioseparation using urea- and imide-bearing chitosan phenylcarbamate derivatives as chiral stationary phases for high-performance liquid chromatography. Chirality 2008, 20, 288-294. [CrossRef] [PubMed]

63. Guntari, S.N.; Nam, E.; Pranata, N.N.; Chia, K.; Wong, E.H.H.; Blencowe, A.; Goh, T.K.; Caruso, F.; Qiao, G.G. Fabrication of chiral stationary phases via continuous assembly of polymers for resolution of enantiomers by liquid chromatography. Macromol. Mater. Eng. 2014, 299, 1285-1291. [CrossRef]

64. Han, X.; An, L.; Cui, H.; Li, H.; Liu, W. Enantioseparation using chitosan tris(3-chlorophenylcarbamate) as a chiral stationary phase for HPLC. Chromatographia 2011, 73, 1043-1047. [CrossRef]

65. Son, S.H.; Jegal, J. Synthesis and characterization of the chiral stationary phase based on Chitosan. J. Appl. Polym. Sci. 2007, 106, 2989-2996. [CrossRef]

66. Tang, S.; Bin, Q.; Chen, W.; Bai, Z.W.; Huang, S.H. Chiral stationary phases based on chitosan bis(methylphenylcarbamate)-(isobutyrylamide) for high-performance liquid chromatography. J. Chromatogr. A 2016, 1440, 112-122. [CrossRef] [PubMed]

67. Tang, S.; Bin, Q.; Feng, Z.-W.; Chen, W.; Huang, S.-H.; Bai, Z.-W. Chitosan bis(halophenylcarbamate)(isobutyrylamide) based chiral stationary phases for enantiomeric separation. New J. Chem. 2016, 40, 9657-9665. [CrossRef]

68. Feng, Z.W.; Chen, W.; Bai, Z.W. Chiral stationary phases based on chitosan bis(4-methylphenylcarbamate)(alkoxyformamide). J. Sep. Sci. 2016, 39, 3728-3735. [CrossRef] [PubMed]

69. Tang, S.; Liu, J.D.; Bin, Q.; Fu, K.Q.; Wang, X.C.; Luo, Y.B.; Huang, S.H.; Bai, Z.W. N-Acylated chitosan bis(arylcarbamate)s: A class of promising chiral separation materials with powerful enantioseparation capability and high eluents tolerability. J. Chromatogr. A 2016, 1476, 53-62. [CrossRef] [PubMed]

70. Zhang, J.; Wang, X.-C.; Chen, W.; Bai, Z.-W. Synthesis of substituted phenylcarbamates of $\mathrm{N}$-cyclobutylformylated chitosan and their application as chiral selectors in enantioseparation. Analyst 2016, 141, 4470-4480. [CrossRef] [PubMed]

71. Feng, Z.W.; Qiu, G.S.; Mei, X.M.; Liang, S.; Yang, F.; Huang, S.H.; Chen, W.; Bai, Z.W. Structural dependence on the property of chiral stationary phases derived from chitosan bis(arylcarbamate)-(amide)s. Carbohydr. Polym. 2017, 168, 301-309. [CrossRef] [PubMed]

72. Wang, J.; Huang, S.H.; Chen, W.; Bai, Z.W. Eluent tolerance and enantioseparation recovery of chiral packing materials based on chitosan Bis(Phenylcarbamate)-(n-Octyl Urea)s for high performance liquid chromatography. Molecules 2016, 21, 1528. [CrossRef] [PubMed]

73. Wang, J.; Xi, J.-B.; Chen, W.; Huang, S.-H.; Bai, Z.-W. High performance chiral separation materials based on chitosan bis(3,5-dimethylphenylcarbamate)-(alkyl urea)s. Carbohydr. Polym. 2017, 156, 481-489. [CrossRef] [PubMed]

74. Liang, S.; Huang, S.-H.; Chen, W.; Bai, Z.-W. High-performance chiral stationary phases based on chitosan derivatives with a branched-chain alkyl urea. Anal. Chim. Acta 2017. [CrossRef] [PubMed]

75. Liu, Y.; Zou, H.; Haginaka, J. Preparation and evaluation of a novel chiral stationary phase based on covalently bonded chitosan for ligand-exchange chromatography. J. Sep. Sci. 2006, 29, 1440-1446. [CrossRef] [PubMed]

(C) 2017 by the authors. Licensee MDPI, Basel, Switzerland. This article is an open access article distributed under the terms and conditions of the Creative Commons Attribution (CC BY) license (http://creativecommons.org/licenses/by/4.0/). 